\title{
Tarihin En Kapsamlı Soğuk Zincir Uygulaması: Koronavirüs (Covid-19) Aşısının Lojistiğinde Karşılaşılan Zorluklar
}

\author{
The Most Comprehensive Cold Chain Application in History: \\ Challenges in Logistics of Covid-19 Vaccine
}

\section{Veli Ahmet ÇEVIK ${ }^{*}$}

\section{$\ddot{0 z}$}

Çin'in Wuhan kentinde 2019 yllının son aylarında ortaya çıkan son yüzyllın en büyük salginlarından biri olan Koronavirüs salginı tüm dünyada yaşamı olumsuz etkilemeye devam etmektedir. Salgın için alınan tedbirler hastaliğın yayılımını durdurmamışve tıbbi gereksinimleri ortaya çıkarmıştır. Hastalıklardan korunmanın en etkili tıbbi yollarından birisi aşılar olmuştur. Koronavirüs hastalğına yönelik aşı çalısmaları, hastalığın ortaya çıkı̧ından kısa bir süre sonra başlamış yaklaşık bir yıllık süre içerisinde yüzden fazla aşı adayı duyurulmuş, gerekli aşamaları geçenlerin dağıtımına onay verilmiştir. Ancak bu aşılardan bazılarının saklanması, taşınması ve dağıtımı için daha öncekilerden farklı olarak sifir derecenin altında oldukça düşük sıcakliklara gerek duyulmuştur. Aşıların bu koşullarda dağıtımı ve teslimi soğuk zincir lojistik uygulamaları altyapısının önemini ortaya çıkartmıştır. Bu çalışmada Dünya Sağlık Örgütünün aşıların lojistiğindeki öncelikli konuları temel alınarak, Koronavirüs aşılarının üretim, tahsis, dağıtım ve uygulanma süreçlerinde ortaya çıkacak olan potansiyel zorlukları araştırılmıştır. Çalışmanın veri kaynağını, daha önce birincil araştırmalarla ortaya çıkarılmış ikincil veriler olan Dünya Sağlı Örgütünün yönergeleri ve çeşitli sektör raporları oluşturmuştur.

\footnotetext{
Özgün Araştırma Makalesi (Original Research Article)

Geliş Tarihi: 04.01.2021 Kabul Tarihi: 31.05.2021

${ }^{(*)}$ Hitit Üniversitesi Osmancık Ömer Derindere Meslek Yüksekokulu, Yönetim ve Organizasyon Bölümü, Lojistik Programı, veliahmetcevik@hitit.edu.tr
}

ORCID ID: https://orcid.org/0000-0003-1981-7275

Üsküdar

Üniversitesi

Sosyal Bilimler

Dergisi, 2021;

sayl: 12 ,

$155-204$ 


\section{Veli Ahmet ÇEViK}

Saklama ve dağıtım faaliyetlerindeki soğuk zincir altyapısının eksikliği, adil olmayan dağıtımı ve aşı karşıtlğııın, aşılama faaliyetlerinin önünde duran en büyük zorluklar olduğu ortaya çıkartılmışır.

Anahtar Kelimeler: Aşı Lojistiği, Aşı Tedarik Zinciri, Koronavirüs, Soğuk Zincir.

\section{Abstract}

The coronavirus pandemic, one of the biggest pandemics of the last century, which emerged in Wuhan, China in the last months of 2019, continues to negatively affect life all over the world. The measures taken for the pandemic did not stop the spread of the disease and revealed medical requirements. Vaccines have been one of the most effective medical ways of preventing diseases. Vaccination studies for coronavirus disease started shortly after the emergence of the disease, and more than a hundred vaccine candidates were announced in about a year, and the distribution of those who passed the necessary

Üsküdar University Journal of Social Sciences, 2021; issue: 12 , $155-204$ stages was approved. However, the storage, transportation and distribution of some of these vaccines required very low temperatures below zero degrees, unlike the previous ones. The distribution and delivery of vaccines under these conditions has revealed the importance of cold chain logistics applications infrastructure. In this study, based on the priority issues of the World Health Organization in the logistics of vaccines, the potential difficulties that will arise in the production, allocation, distribution and application processes of coronavirus vaccines have been investigated. The data source of the study was the guidelines of the World Health Organization and various industry reports, which were secondary data previously revealed through primary research. Lack of cold chain infrastructure in storage and distribution activities, unequal distribution and anti-vaccination were found to be the biggest challenges facing vaccination activities.

Keywords: Vaccine Logistics, Vaccine Supply Chain, Coronavirus, Cold Chain.

\section{Giriş}

2019 yılının son aylarında Çin'in Wuhan kentinde ortaya çıkan son yüzyılın en büyük salgınlarından biri olan Koronavirüs salgını tüm dünyada yaşamı olumsuz etkilemeye devam etmektedir. Aradan geçen yaklaşık bir yıllık sürede, hastalığa karşı kesin bir tedavi yönteminin bulunamamasıyla, sağlık yetkilileri salgına karşı alınabilecek en önemli 


\section{Covid-19 Aşısının Lojistiğinde Karşılaşılan Zorluklar}

tedbirlerin maske, mesafe ve temizlik olduğunu duyurmuşlardır. Alınan tedbirler hastalığın yayılmasını yavaşlatmıştır ancak durduramamıştır. Durdurulamayan salgın, küresel çapta 59 milyondan fazla vaka sayısına ve 1,5 milyondan fazla kişinin hayatını kaybetmesine yol açmıştır. ${ }^{1}$ Hastalığın küresel çapta salgına dönüşmesiyle dünyanın önde gelen laboratuvarları, aşı çalışmalarına başlamıştır. Salgın hastalıkların önlenmesi için en etkili ve en düşük maliyetli yöntemlerden birinin aşı olduğu bilinmektedir. Dünya Sağlık Örgütü (DSÖ) raporlarına göre, geliştirilen aşılarla yaşamı tehdit eden 20'den fazla hastalık önlenerek her yıl 2-3 milyon ölüm önlenmektedir. ${ }^{2}$

İlk koronavirüs vakaları 2019 yılının Aralık ayı sonunda Çin'de tespit edilmiş, 21 Ocak 2020 tarihinde Amerika Birleşik Devletleri'ne (ABD) ve üç gün sonra Avrupa'ya ulaşmıştır. Ancak dünyanın önde gelen ilaç şirketlerinin aşı üzerinde çalıştıklarını açıklamaları Mart ayı ortalarını bulmuştur. DSÖ'nün pandemi ilan etmesinden beş gün sonra 16 Mart 2020 tarihinde ABD merkezli Moderna Şirketi, koronavirüs aşısı güvenlik denemelerine başlayan ilk şirket olmuş ve sonraki günlerde başka şirketlerde kendi denemelerini başlatmıştır. 12 Kasım 2020 tarihinde ise 202 şirketin aşı geliştirdiği ve bunlardan 47'sinin klinik deneme aşamasında olduğu bildirilmiştir. ${ }^{3}$ İlk vakanın ortaya çıkmasından sonra geçen 11 aylık süreçte aşı geliştirmede oldukça iyi bir yol alındığı görülmektedir. Ancak aşının bulunması hastalığın kolayca önleneceği anlamına gelmemektedir. Aşının lojistiği ve dağıtımı aşının keşfi kadar önemli bir konudur. Çünkü

\footnotetext{
${ }^{1}$ Worldometers.info, "Coronavirus Update (Live): 59,562,713 Cases and 1,402,934 Deaths from COVID-19 Virus Pandemic - Worldometer," 24 Kasım 2020, https:/ /www. worldometers.info/coronavirus/?

${ }^{2}$ WHO, "Vaccines and immunization," 24 Kasım 2020, https://www.who.int/ health-topics/vaccines-and-immunization\#tab=tab_1.

${ }^{3}$ WHO, "Draft landscape of COVID-19 candidate vaccines," 24 Kasim 2020, https:// www.who.int/publications/ m/item/draft-landscape-of-covid-19-candidate-vaccines.
} 


\section{Veli Ahmet ÇEviK}

günümüzde üzerinde çalş̧ıllmakta olan aşıların bazıları, soğuk tedarik zinciri olarak adlandırılan, sıfır derecenin oldukça altında, $-80^{\circ} \mathrm{C}$ ye kadar düşebilen ortamlarda muhafaza edilebilmektedir. Aşının bu koşullarda depolanması, dağıtılması ve teslim edilmesi oldukça büyük bir sorunu teşkil etmektedir. Söz konusu sorunların araştırıldığı bu çalışmanın ilk kısmında daha önce konu ile ilgili yapılan çalısmaların taraması ve Covid 19 salgını hakkında bilgi verilmiş, ardından soğuk zincir lojistiği açıklanarak soğuk zincir lojistiğinin uygulama alanlarından olan aşı lojistiğine değinilmiştir. Sonraki bölümlerde ise aşının üretiminden, aşı karşıtlığı da dahil olmak üzere son kullanıcıya uygulanma aşamasına kadar aradaki süreçte karşılaşılan zorluklar araştırılmıştır.

Üsküdar

University

Journal of Social

Sciences, 2021;

issue: 12 ,

155-204

\section{Literatür Taraması}

Soğuk zincir lojistiğinin uygulaması karmaşık ve hassas sistemler gerektirdiğinden, bu konu ile ilgili yapılan araştırmalarda soğuk zincirin farklı açlarına bakılmıştır. Chaudhuri ve arkadaşları veri analitiğini kullanarak soğuk zincir lojistiğinde karar verme yöntemlerini araştırdıkları çalışmalarında soğuk zincir sürecindeki tüm oyuncuların, verilerin soğuk zincirde daha iyi kararlar almak için nasıl etkili bir şekilde kullanılabileceğini anlamaları ve amaca uygun özel teknolojilere yatırım yapmaları gerektiğini ortaya çıkarmışlardır. ${ }^{4}$

Bozulabilir ürünlerin soğuk zincir lojistiği için bir esneklik modelini çalısan Ali ve arkadaşları, soğuk zincir lojistiğinde risk kaynaklarının azaltılması ve beklenmedik durumları tahmin etme beceresinin, son tüketiciler için operasyonların sürekliliğini sağlanmasına katkı sağladığı sonucuna varmışlardır.

\footnotetext{
${ }^{4}$ Atanu Chaudhuri et al., "Decision-Making in Cold Chain Logistics Using Data Analytics: A Literature Review," The International Journal of Logistics Management, 2018.

${ }^{5}$ Imran Ali, Sev Nagalingam, and Bruce Gurd, "A Resilience Model for Cold Chain Logistics of Perishable Products," The International Journal of Logistics Management, 2018.
} 


\section{Covid-19 Aşısının Lojistiğinde Karşılaşılan Zorluklar}

Dipika ve arkadaşları ise aşı soğuk zincirinde aşıların yanlışlıkla dondurulması sorununu inceledikleri çalışmalarında, soğuk zincirin tüm aşamalarında aşıların donma sıcaklıklarına maruz kalabileceğini tespit etmişlerdir. ${ }^{6}$

Türkiye'de soğuk zincir konusunda araştırmaların gıda üzerine yoğunlaştığı görülmektedir. Erzurum sütçülük sektöründe soğuk zincir uygulamalarını araştıran Yavuz ve arkadaşları ${ }^{7}$ süt üretimindeki dalgalanmalara esneklik sağlayacak sistemler önermiştir. Korucuk ${ }^{8} 2018$ yılında gerçekleştirdiği araştırmasında, soğuk zincir taşımacılığı yapan işletmelerde 3PL firma seçimi araştırmasında en önemli ölçütün "İşletme Performansı” olduğunu tespit etmiştir. Karaman ilindeki soğuk hava depolarının mevcut durumu ve sorunlarını araştıran Nizamlığlu ve Gökmen, soğuk depo sektöründeki örgütlenme eksikliği ve soğuk hava depolarında modernizasyonun eksikliğini ortaya çıkartmışlardır.9 Yazıcı ise Covid-19'un soğuk zincir lojistiğine etkisini araştırmış ve beklenmedik durumlara karşın hazırlıklı olmak için altyapıya önem verilmesi gerektiği vurgulamıştır. ${ }^{10}$ Sağlık alanında soğuk zincir çalışmaları ise kısıtlı sayıda gerçekleştirilmiştir. Küçüktürkmen ve arkadaşlarının hazırladıkları derlemede özel saklama koşulu gerektiren veya soğuk zincire tabi ilaçlar ve

${ }^{6}$ Dipika M. Matthias et al., "Freezing Temperatures in the Vaccine Cold Chain: A Systematic Literature Review,” Vaccine 25, no. 20 (May 16, 2007): 3985.

${ }^{7}$ Fahri Yavuz, Ayşe Sezgin, and Okan Demir, "Erzurum Sütçülük Sektöründe Soğuk Zincir İyi Uygulama Örneklerinin Oluşturulması ve Yayınlaştırılması Üzerine Bir Çalışma,” Tarım Ekonomisi Araştırmaları Dergisi 2, no. 1 (2016): 7.

${ }^{8}$ Selçuk Korucuk, "Soğuk Zincir Taşımacıllı̆ı Yapan Işletmelerde 3pl Firma Seçimi: İstanbul Örneği,” Iğdır Üniversitesi Sosyal Bilimler Enstitüsü Dergisi 16 (2018): 358.

${ }^{9}$ Nizam Mustafa Nizamlıoğlu and Süleyman Gökmen, "Karaman Ilindeki Soğuk Depolarının Mevcut Durumu, Sorunları ve Çözüm Önerileri," Derim Dergisi 34, no. 1 (2017): 49

${ }^{10}$ Sabire Yazıcı, “Covid-19'un Soğuk Zincir Lojistiğine Etkisi," Journal of Awareness 5, no. 3 (2020): 398. 


\section{Veli Ahmet ÇEViK}

uygulamaları değerlendirerek, çalışmalarında uluslararası düzenlemeler, kılavuzlar ve Türkiye'deki soğuk zincir uygulamalarına yer vermişlerdir. ${ }^{11}$

\section{Covid-19 Salgını}

2019 yllının son günlerinde Çin'in Wuhan kentinde teşhisi konulamayan zatürre benzeri vakaların görülmesinin ardından, Wuhan Belediyesi Sağlık Komisyonu, Wuhan'da bir dizi zatürre vakasının ortaya çıktığını Dünya Sağlık Örgütü’ne bildirmiştir.'2 Salgın çok kısa sürede Çin dışına yayılmış ve 80 bini Çin'de olmak üzere dünyada yaklaşı 118 bin vakanın görüldüğü 11 Mart 2020 tarihinde DSÖ tarafından Pandemi ilan edilmiştir. 9 Ocak'ta ilk ölümün gerçekleşmesinden yaklaşık bir ay sonra 10 Şubat'ta ölüm sayısı bine ulaşmış ve 28 Eylül'de küresel çapta bir milyon

Üsküdar University Journal of Social Sciences, 2021; issue: 12 , 155-204 ölüm vakası gerçekleşmiştir. ${ }^{13}$ Salgının şiddetinin artmaya başlamasının ardından tüm dünyada kısıtlamalara gidilmeye başlanmış, uluslararası uçuşlar iptal edilmiş ticaret durma noktasına gelmiştir. İlk vakanın görüldügü Çin'in belirli eyaletlerinde 23 Ocak'ta yaklaşık 60 günlük ilk karantina uygulamasına başlanmış ve dünya genelinde 101 ülkede Mart ayı başlarında karantina uygulanmasına başlanmıştır.

Ülkelerin sınırlarının kapatılması uluslararası mal akışını kesmiş, insanlar panik alışverişine yönelmiş ve market raflarına temizlik ürünlerinin tedariki sağlanamamıştır. ${ }^{14}$ Uzun süreli karantinalar nedeniyle ulaşım araçlarının çalışmaması, ekonomik aksaklıkların meydana gelmesi

${ }^{11}$ Küçüktürkmen, Berrin, and A Bozkır, “Özel Saklama Koşulu Gerektiren Veya Soğuk Zincire Tabi Ilaçlar ve Uygulamalar Açısından Değerlendirmeler,” Türk Hijyen ve Deneysel Biyoloji Dergisi. Interest Group, 2018.

${ }^{12}$ WHO, “WHO Time Line - COVID-19," 24 Kasim 2020, https://www.who.int/news/ item/27-04-2020-who-timeline-covid-19.

${ }^{13}$ BBC, “Covid-19: Milestones of the global pandemic," 25 Kasim 2020, https://www. bbc.com/news/world-54337098.

${ }^{14}$ Serpil Aday and Mehmet Seckin Aday, "Impact of COVID-19 on the Food Supply Chain," Food Quality and Safety 4, no. 4 (2020): 169. 


\section{Covid-19 Aşısının Lojistiğinde Karşılaşılan Zorluklar}

dünya çapında üretim ve hareketlilikte bir yavaşlamaya yol açarak küresel petrol talebinde önemli bir düşüşe neden olmuştur. Sosyal mesafe kuralları, tüm işletmeleri müşterilerini nasıl güvenli bir şekilde mesafeli tutacakları konusunda çok düşünmeye zorlamıştır. Bu firmaların amacı insanları bir araya getirmek olduğundan etkinlik şirketleri için bu kurallar büyük bir sorun teşkil etmiştir. Ticaret fuarları, konferanslar, konserler ve spor müsabakaları seyirciden yoksun şekilde faaliyet göstermek zorunda kalmıştır. Söz konusu şirketlerin hisseleri Ocak ayından bu yana kayıplarını çoğunlukla telafi etmiş olsa da, The Economist tarafından yayımlanan rapora göre "kalabalık işletmelerin” piyasa değeri 234 milyar dolardan 183 milyar dolara düşmüştür. ${ }^{15}$ Nisan ayında, Uluslararası Enerji Ajansı (IEA) petrole olan talebin bir yıl öncesine göre \%30 azaldığını ve 1995’ten beri görülmeyen bir düzeye ulaştığını tahmin etmiştir. ${ }^{16}$ Uluslararası Hava Taşımacılı̆̆ıBirliği(IATA) verilerine görehavacılıkvedestekhizmetlerinde \%52,5 oranında iş kaybı yaşanmış, havacılık gelirlerinde \%66'ya varan kayıplar yaşanmıştır. ${ }^{17}$ Uluslararası turist girişleri 2020 Ocak-Ağustos döneminde \%70 azalmış ve bu oran 700 milyon daha az uluslararası turist anlamına gelmektedir. ${ }^{18}$ Pandeminin neden olduğu tedarik zinciri kesintileri, talep daralmaları ve küresel ekonomik belirsizliklerin devam ettiği 2020 yılında, Birleşmiş Milletler Ticaret ve Kalkınma Konferansı verilerine göre uluslararası deniz ticareti hacminin \%4,1 oranında düşeceği

\footnotetext{
${ }^{15}$ The Economist, “The roar of the crowd - Nothing can beat a live event," 3 Arallk 2020, https://www.economist. com/special-report/2017/02/09/nothing-can-beat-a-live-event. ${ }^{16}$ IEA, “Oil Market Report- Analysis - IEA,” 26 Kasım 2020, https://www.iea.org/ reports/oil-market-report-april-2020.

${ }^{17}$ IATA, “IATA - Home,” 25 Kasim 2020, https://www.iata.org/.

${ }^{18}$ UNWTO, "Impact assessment of the COVID-19 outbreak on international tourism," 25 Kasim 2020, https: / www.unwto.org/impact-assessment-of-the-covid-19-outbreakon-international-tourism.
}

Üsküdar Üniversitesi Sosyal Bilimler Dergisi, 2021; sayl: 12 , 155-204 


\section{Veli Ahmet ÇEViK}

tahmin edilmektedir. ${ }^{19}$ Dünya ekonomisinin 2020 yılında, ikinci dünya savaşından bu yana en derin gerileme olan \%4'ün üzerinde küçülmesi tahmin edilmektedir. Salgın, küresel ölçekte hareketliliği durduran niteliği ile dünyayı birçok boyutta etkileme kapasitesi ile küresel bir tehdit olarak karşımıza çıkmıştır. ${ }^{20}$

\section{Soğuk Zincir}

Gıdaların özelliklerini kaybetmeden saklanması, insanlık tarihinden beri insanların en önemli ihtiyaçlarından biri olmuştur. İnsanlık tarihinin ilk dönemlerinde avcılık ve toplayıcılık faaliyetleriyle bulunan gıdalar bir sonraki kıtlık mevsimiyle baş edebilmek için uygun gıda koruma teknikleriyle bozulmadan saklanması ve tarımsal üretime geçildikten

Üsküdar University Journal of Social Sciences, 2021; issue: 12 , $155-204$ sonra ürünlerin bir sonraki hasat dönemine kadar muhafaza edilmesi gerekmiştir. ${ }^{21} \mathrm{Bu}$ amaçlar doğrultusunda günümüze kadar gıdaların korunması için birçok gelişme kaydedilmiş ve gelişen teknolojiler sayesinde gıdalar uzun süre bozulmadan tüketilmeye hazır şekilde muhafaza edilebilmektedir. Gelişen soğutma teknolojileri sadece gıdaları koruma amacına hizmet etmekle kalmamış, yaşam alanlarının aşırı sıcaklardan etkilenmemesi için soğutulmasını sağlamaya başlamıştır. Tıp alanında yaşanan gelişmelerle birlikte ilaçların ve sağlık malzemelerinin ısı kontrolüne ihtiyaç duyulmuş ve soğutma teknolojileri bu ihtiyaca da cevap vermeye başlamıştır.

Soğuk zincir, gıda ürünlerinin kalitesini ve güvenliğini sağlamak için tasarlanmış, üst düzey tedarikçiler ve tüketiciler arasında soğutulmuş

${ }^{19}$ UNCTAD, “Review of Maritime Transport 2020,” 25 Kasım 2020, https://unctad.org/ webflyer/review-maritime -transport-2020.

${ }^{20}$ İbrahim Arslan and Soner Karagül, "Küresel Bir Tehdit (COVID-19 Salgını) ve Değişime Yolculuk,” Üsküdar Üniversitesi Sosyal Bilimler Dergisi, no. 10 (2020): 46.

${ }^{21}$ Alain Testart et al., "The Significance of Food Storage among Hunter-Gatherers: Residence Patterns, Population Densities, and Social Inequalities [and Comments and Reply]," Current Anthropology 23, no. 5 (1982): 524; 


\section{Covid-19 Aşısının Lojistiğinde Karşılaşılan Zorluklar}

malların kesintisiz sıcaklık kontrollü taşıma ve depolama sistemidir. ${ }^{22-23}$ Başka bir ifadeyle soğuk zincir, kesintisiz bir soğutmalı üretim, depolama, depo ve lojistik faaliyetler dizisidir. ${ }^{24}$ Dış çevre sıcaklığından etkilenen ürünlerin korunmasını iyileştirmek için tedarik zinciri boyunca soğutma uygulandığı tedarik zincirine soğuk zincir denilmektedir.

Soğuk zincir lojistiği, bozulabilir ürünlerinin raf ömrünü uzatmak için düşük ve kontrollü bir sıcaklık aralığında kesintisiz taşıma ve depolama faaliyetlerini içermektedir. ${ }^{25}$

$\mathrm{Bu}$ soğuk zincir öğelerinin örnekleri, deniz ürünleri ve dondurma gibi derin dondurulmuş ürünler $\left(-25^{\circ} \mathrm{C}\right.$ ile $\left.-30^{\circ} \mathrm{C}\right)$, dondurulmuş et ve dondurulmuş unlu mamuller gibi dondurulmuş ürünler $\left(-10^{\circ} \mathrm{C}\right.$ ile $\left.-20^{\circ} \mathrm{C}\right)$, meyveler, sebzeler ve taze etler gibi soğutulmuş ürünler $\left(2^{\circ} \mathrm{C}\right.$ ile $\left.4^{\circ} \mathrm{C}\right)$, ilaçlar ve aşılar gibi farmasötik ürünlerdir $\left(2^{\circ} \mathrm{C}\right.$ ile $\left.8^{\circ} \mathrm{C}\right) .^{26}$

Meyveler ve sebzeler, süt ürünleri, balıklar ve et ürünleri gibi çabuk bozulan yiyecekler, hasattan veya üretimden sonra sınırlı bir raf ömrüne sahiptir. Gida ürününün pazarlanamaz veya tüketilemez hale gelmesi, kendisine ve bir dizi çevresel faktöre bağlıdır. Bu çevresel faktörler arasında saklama sıcaklığı, basınç, bağıl nem ve çevreleyen gazın bileşimi ve hızı yer

${ }^{22}$ Savaş Güler, “Gıdaların Muhafazasında Soğuk Zincir Süreci,” 2019, www.essiad.org.tr.

${ }^{23}$ Nodali Ndraha et al., "Time-Temperature Abuse in the Food Cold Chain: Review of Issues, Challenges, and Recommendations," Food Control (Elsevier Ltd, July 1, 2018).

${ }^{24}$ S Balachandar and R Chinnaiyan, "Reliable Pharma Cold Chain Monitoring and Analytics through Internet of Things Edge," in Emergence of Pharmaceutical Industry Growth with Industrial IoT Approach (Elsevier, 2020), 133.

${ }^{25}$ Ali, Nagalingam, and Gurd, "A Resilience Model for Cold Chain Logistics of Perishable Products."

${ }^{26}$ Nader Al Theeb et al., "Optimization of Vehicle Routing with Inventory Allocation Problems in Cold Supply Chain Logistics," Computers \& Industrial Engineering 142 (2020): 106341. 


\section{Veli Ahmet ÇEviK}

alır. ${ }^{27}$ Ürünlerin üretildiği noktadan son kullanıcıya ulaşana kadar aradaki süreçte ortamın ısı değerleri standart olmalıdır. Bu standart koşulların sağlanabilmesi için soğuk zincirde olması gereken bir takım unsurlar vardır. Soğuk zincirin ana unsurları şunları içermektedir: $:^{28}$

- Soğutma sistemleri: Bozulabilir ürünleri işleme, depolama ve nakliye için uygun sıcaklığı sağlayan sistemlerdir.

- Soğuk hava deposu: Uzak bir pazara gönderilmeyi bekleyen, işleme ve dağıtım için bir ara yerde veya dağıtım için pazara yakın bir sürede malların uygun sıcaklıklarda depolanması için kullanılan tesislerdir.

- Soğuk taşıma: Sabit sıcaklıklarını, nem koşullarını ve bütünlüklerini

Üsküdar

University

Journal of Social

Sciences, 2021;

issue: 12 ,

155-204 korurken malları taşımak için kullanılan ısı kontrollü taşıma araçlarıdır.

- Soğuk işleme ve dağıtım: Malların dönüştürülmesi ve işlenmesi için tesislerin yanı sıra sağlık koşullarının sağlanması ve yükleri uygun koşullarda dağıtmaktır.

İlaç endüstrisi, ürün yaşam döngüsü boyunca malları korumak için tüm operasyonlarda kalite gerekliliğine karşı çok hassastır. Nakliye sırasında anormal sıcaklık değişimleri, hassas ürünlerin bütünlüğünü ciddi şekilde tehlikeye atabilecektir. ${ }^{29}$ İlaç sektöründe de her geçen gün soğuk zincire olan ihtiyaç artmaktadır. 2018 yılında hazırlanan bir rapora göre toplam ilaç ihracatının yaklaşık yarısının Almanya, İsviçre, Belçika, $A B D$ ve İngiltere'nin arasında bulunduğu dört ülkeden dünyanın geri

\footnotetext{
${ }^{27}$ Samuel Mercier et al., "Optimized Cold Chain to Save Food," in Saving Food (Elsevier, 2019), 203.

${ }^{28}$ Jean-Paul Rodrigue and Theo Notteboom, The Geography of Transport Systems, Routledge, 2014,165 .

${ }^{29}$ Nirmal Kumar and Ajeya Jha, "Application of Principles of Supply Chain Management to the Pharmaceutical Good Transportation Practices," International Journal of Pharmaceutical and Healthcare Marketing, sayı: 13 (2019):307
} 
kalanına yapıldığı tahmin edilmektedir. ${ }^{30}$ Benzer şekilde, Mart 2021 tarihi itibariyle üretilen bir milyar Covid-19 aşısının yarısından fazlası Çin, ABD ve Hindistan'da üretilmiştir (Grafik 3). Bu nedenle ilaçların ve aşıların satışları sırasında ürün hareketliliği göz önüne alındığında, soğuk zincir faaliyetleri önümüzdeki yıllarda da yükselişte olacaktır.

Yaygın veya çok yaygın olmayan sağlık sorunları arttıkça tedavilere yönelik beklentiler de artmaktadır. Tüm dünyayı etkisi altına alan son salgından kurtulmanın en etkili yöntemi olan aşılar da bu beklentilerden yalnızcabiridir.Üretilenilaçların sınırlırafömrüvesıcaklıkgereksinimlerine sahip daha karmaşık bileşenler içerecek şekilde gelişmesi, tüm tedarik zinciri boyunca sıcaklık kontrolünü ve izleme ihtiyacını artırmıştır.

\section{Koronavirüs (Covid 19) Aşısı ve Lojistiği}

Aşılama, insanların hayatlarını kurtarmak ve sağlıklarını iyileştirmek için temiz su sağlamaktan sonra, dünyadaki en etkili halk sağlığ müdahalelerinden biri olmuştur. ${ }^{31}$ Tahminlere göre aşılama sayesinde 9 bulaşıcı hastalığın ölüm ve hastalık oranı \%97,8 düşürülmüştür. ${ }^{32}$

1974 yılında Dünya Sağlık Örgütü tarafından Genişletilmiş Aşılama Programı (EPI) oluşturulmuş, bu program ile küresel çapta çiçek hastalığını ortadan kaldırma amacıyla tüm ülkelerdeki çocukların hayat kurtaran aşılardan yararlanması amaçlanmıştır. 1976 yılında Londra Çocuk Sağlığı Enstitüsü’nden Profesör David Morley, DSÖ’nün küresel olarak rutin aşılama hizmetleri oluşturma isteğini kısıtlayan aşağıdaki üç kritik konuyu ele almak için DSÖ’nün Genişletilmiş Aşılama Programı

\footnotetext{
${ }^{30}$ Daniel Workman, “Drugs and Medicine Exports by Country,” World's Top Exports, 27 Mayıs 2021. http://www. worldstopexports. com/drugs-medicine-exports-country, 2019. ${ }^{31}$ İngiltere Halk Sağlığı, "Why vaccinate? - Public health matters,” 27 Kasım 2020, https:// publichealthmatters. blog.gov.uk/2014/05/01/why-vaccinate/.

${ }^{32}$ Qi Lin, Qiuhong Zhao, and Benjamin Lev, "Cold Chain Transportation Decision in the Vaccine Supply Chain,” European Journal of Operational Research 283, no. 1 (2020): 182.
}

Üsküdar Üniversitesi Sosyal Bilimler Dergisi, 2021; sayı: 12 , 155-204 


\section{Veli Ahmet ÇEViK}

içinde bir ekip kurmasını önermiştir. Aşılama işlemlerini kısıtlayan önemli konular ise;

- Isıya duyarlı aşıların sıcaklı̆̆ını izleyecek sistemlerin olmaması,

- Aşıların depolanması ve taşınması için uygun ekipmanın olmaması,

- Aşılarla başa çıkmak için yeterli sayıda eğitimli personel olmamasıdır. ${ }^{33}$

İlaç endüstrisi, ilaçlarının çoğunun ısı kontrolü gereksinimi olmadığı için, tarihsel olarak büyük bir soğuk zincir lojistiği kullanıcısı olmamıştır. Ancak yakın geçmişte, biyolojik adı verilen yeni bir ilaç sınıfının ortaya çıkmasıyla birlikte soğuk zincir faaliyetlerinde bir artış yaşanmıştır. Çoğu biyolojik sınıftaki ilaçlar, hem sıcaklık hem de zaman kontrollü dağıtım gerektirmektedir. 2017'de Amerikan Gıda ve İlaç Dairesi (Food

Üsküdar University Journal of Social Sciences, 2021; issue: 12 , $155-204$ and Drug Administration) tarafından onaylanan 57 üründen 28'i soğuk zincir ürünleri olmuş ve bunlardan 23'ünün 2-8 derece sıcaklık koşulları ve beşinin 0 derecenin altında oldukça düşük sıcaklık koşullarında (kriyojenik) saklanması gerekmektedir. ${ }^{34}$

Bu nedenle, Dünya Sağlık Örgütü (DSÖ) aşağıdaki aşıların $0-10^{\circ} \mathrm{C}$ 'de saklanmasını ve taşınmasını önermektedir: Difteri-tetanoz içeren aşılar, tetanoz toksoidi $(\mathrm{TT})$, hepatit $\mathrm{A}$ ve $\mathrm{B}$, insan papilloma virüsü (HPV), menenjit $\mathrm{C}$, pnömokok (PCV), kolera, influenza, haemophilus influenza $\mathrm{b}$ (Hib), tifo ve inaktive poliovirüs (IPV).

\section{Sıcaklığa ve Işığa Duyarlılık}

DSÖ 2015 yılında, soğuk zincir ekipman performansının rutin izlenmesi, sıcaklık haritalaması ve tedarik zinciri sıcaklıklarını değerlendirmek için çalışmaların doğru uygulanması için Aşı Yönetimi

\footnotetext{
${ }^{33}$ John Lloyd and James Cheyne, "The Origins of the Vaccine Cold Chain and a Glimpse of the Future," Vaccine 35, no. 17 (April 19, 2017

${ }^{34}$ Harjotsingh Chance, “Cold Chain Logistics in Pharma," 27 Kasim 2020, https: / www. hcltech.com/blogs/cold-chain-logistics-pharma.
} 


\section{Covid-19 Aşısının Lojistiğinde Karşılaşılan Zorluklar}

El Kitabı yayımlamıştır. ${ }^{35}$ Söz konusu kitapta aşıların sıcaklığa ve ışığa duyarlılığının öneminden bahsedilerek, aşılara uygun yönlendirmeler yapılmıştır. Aşılanan hastayı koruyacak bir bağışıklık kazanmak için etkili bir aşı uygulamak esastır. Aşılar, donma sıcaklıklarına, ısıya ve ışığa maruz bırakıldığında çeşitli derecelerde zarar görebilecek hassas biyolojik ürünler olduğundan, aşının etkisi bir kez kaybedildiğinde, tekrar ilk etkisini kazanılamayacak olmasından dolayı aşılar ve seyrelticilerle uğraşan herkes, programlarında kullanılan ürünlerin sıcaklık hassasiyetlerini ve ürünlerin tavsiye edilen saklama ve dağıtım sıcaklıklarını bilmesi gerekmektedir. Tüm aşılar zamanla etkisini kaybetmekte olup, 1sı bu etkinliğin kaybını hızlandırmaktadır. Aşı türleri ısıya duyarlılıklarına göre değişiklik göstermektedir. Herhangi bir aşı türü için, ısı hassasiyeti de farklı üreticiler tarafından yapılan markalar arasında farklılık göstermektedir. Dondurularak kurutulmuş aşılar ve kızamık aşıları ile oral çocuk felci aşısı (OPV) dahil olmak üzere birçok aşı donmaya dayanaklıdır.

Aşı Yönetimi El Kitabı́na göre Dünya Sağlık Örgütü tıbbi malzemeleri sıcaklık kontrollü, zamana ve sıcaklığa duyarlı farmasötik ürünler olarak gruplandırmıştır:

- Sıcaklık kontrollü: Sıcaklığın, önceden tanımlanmış kesin sınırlar dahilinde çevredeki ortamdan farklı bir seviyede aktif veya pasif olarak kontrol edildiği herhangi bir ortamı içerir.

- Zamana ve sıcaklığa duyarlı farmasötik ürün (TTSPP): Önceden tanımlanmış çevresel koşullar içinde ve / veya önceden tanımlanmış zaman sınırları dahilinde depolanmadığı veya taşınmadığı zaman, artık başlangıçta amaçlandığı gibi çalışmayacağı ölçüde bozulan herhangi bir farmasötik ürün.

Koronavirüs pandemisinin sona ermesi için birçok mücadelenin başarılı şekilde ilerlemesi gerekmektedir. Bu mücadelelerin ilk başında

\footnotetext{
${ }^{35}$ WHO, "Qualification of temperature-controlled storage areas," 6 Aralık 2020, https://www. who.int/biologicals /expert_committee/Supplement-7-TS-qualification-storage-areas
} 


\section{Veli Ahmet ÇEviK}

ilaç şirketlerinin güvenli ve etkili bir aşı geliştirmesi ve milyarlarca insanın bu aşıya rıza göstermesi gelmektedir. Ancak asıl mücadele, tüm bunların olabilmesi için aşıların uygun taşınma koşulları altında son noktaya kadar taşınması ve dağıtılmasıdır. Küresel olarak bir milyardan fazla insanın potansiyel aşıya erişimini sağlamak, aşının kendisini geliştirmek kadar kritiktir.DahaöncekiSarsve Mershastalıklarıüzerindekiaşıçalışmalarından elde edilen bilgiler Covid-19 aşılarını kısa sürede geliştirmede önemli rol oynamıştır. Söz konusu aşıların klinik denemelerinin dört aşaması vardır. Dünya Sağlık Örgütü’ne göre bu dört aşama şu şekilde belirtilmiştir;

Birinci faz çalışmaları, güvenli bir doz aralığını değerlendirmek ve yan etkileri belirlemek için küçük bir grup insanda ilk kez aday aşıları değerlendirir.

Üsküdar

University

Journal of Social

Sciences, 2021;

issue: 12 ,

155-204

İkinci faz çalışmaları, olumsuz etkileri izlemek için daha büyük bir grup insandaki aday aşıları değerlendirir.

Üçüncü faz çalışmaları, geniş bir nüfus üzerinde ve birkaç ülkede yürütülmektedir. Bunlar genellikle bir aşı onaylanmadan önce atılan son adimdir.

Dördüncü faz çalışmaları, bir aşı adayı onaylandıktan ve genel nüfusa dağıtıldıktan sonra gerçekleştirilir. ${ }^{36}$

2020 Yılı başlarında gen dizilimi çözülen Sars-Cov-2 hastalığına karşı geliştirilmeye başlanan aşılar, gün geçtikçe 3. Fazı başarıyla geçmekte ve ulusal çapta uygulanabilme izinlerini almaktadır. ${ }^{37}$ Ancak hala bu aşıların nasıl dağıtılacağı, ilk dozlara kimin erişeceği ve kitleler için yeterli miktarların ne zaman mevcut olacağı gibi sorular devam etmektedir. Dünya Sağlık Örgütü acil durum başkanının yaptığı açıklamada, "en iyi tahminlerinin" dünya çapında, teyit edilen vaka sayısının 20 katından fazla,

\footnotetext{
${ }^{36}$ WHO, "Clinical Trials," 27 Mayıs 2021, https://www.who.int/health-topics/ clinical-trials.

37 Philip Ball, “The Lightning-Fast Quest for COVID Vaccines - and What It Means for Other Diseases," Nature 589, no. 7840 (January 1, 2021): 17.
} 


\section{Covid-19 Aşısının Lojistiğinde Karşılaşılan Zorluklar}

yaklaşı 10 kişiden 1'inin koronavirüs bulaşmış olabileceğini gösterdiğini ifade etmiştir. Yaklaşık 7,6 milyarlık mevcut dünya nüfusu temelinde 760 milyondan fazla insanı bulacak olan tahmin, hem DSÖ hem de Johns Hopkins Üniversitesi tarafından kaydedilen 65 milyon doğrulanmış vaka sayısının çok üzerindedir. ${ }^{38}$

Minnesota Üniversitesi Bulaşıcı Hastalık Araştırma ve Politikaları Merkezi'nden (CIDRAP) yapılan modelleme çalışması, virüsü durdurmak için insanların yaklaşık \%70'inin bağışıklık kazanması gerektiğini ortaya koymuştur. ${ }^{39}$

Lojistik, tanımı itibariyle doğru ürünü, doğru miktarda ve doğru koşullarda, doğru müşteriye doğru fiyata doğru zamanda doğru yerde teslim etmektir. ${ }^{40}$ Lojistiğe konu aşı olunca aşının üretimi, kimlere dağıtılacağı ve nasıl dağıtılacağı önem arz etmektedir. Bu çalışma, Dünya Sağlık Örgütü yayınları ve Duijzer ve arkadaşlarının aşı tedarik zinciri hakkındaki literatür taraması çalışmasındaki veriler kullanarak yapılandırılmıştır. Duijzer ve arkadaşları gerçekleştirdikleri çalışmalarında aşı tedarik zincirinde dört bileşeni ortaya çıkartmışlardır. ${ }^{41}$ Bunlar;

1. Ürün: Ne tür bir aşı kullanılmalıdır?

2. Üretim: Kaç doz ve ne zaman üretilmelidir?

3. Tahsis: Kimler aşı olmalıdır?

4. Dağıtım: Aşılar nasıl dağıtılmalıdır?

${ }^{38}$ Jamey Keaten, “WHO: 10\% of world's people may have been infected with virus," 12 Aralık 2020, https://news.yahoo.com/10-worlds-people-may-infected-114759146.html ${ }^{39}$ Kristine A Moore et al., "COVID-19: The CIDRAP Viewpoint: Part 1: The Future of the COVID-19 Pandemic: Lessons Learned from Pandemic Influenza,” CIDRAP: University of Minnesota. April 30th, 2020,5.

${ }^{40}$ Paul D Larson, "A Note on Mail Surveys and Response Rates in Logistics Research," Journal of Business Logistics 26, no. 2 (2005): 212.

${ }^{41}$ Lotty Evertje Duijzer, Willem van Jaarsveld, and Rommert Dekker, "Literature Review: The Vaccine Supply Chain,” European Journal of Operational Research 268, no. 1 (2018): 175 . 


\section{Veli Ahmet ÇEViK}

\section{Ürün ve Üretim:}

Aşılama, insanları onlarla temas etmeden önce zararlı hastalıklara karşı korumanın basit, güvenli ve etkili bir yoludur. Belirli enfeksiyonlara karşı direnç oluşturmak için vücudun doğal savunmasını kullanır ve bağışıklık sistemini güçlendirir. ${ }^{42}$

Tarihte aşıların geliştirilmesi oldukça uzun yıllar almıştır. Ancak, Çinli bilim adamlarının yeni virüsün gen dizisini yayınlamasından yalnızca altı hafta sonra biyoteknoloji şirketi Moderna teste başlamak için aşı denemelerini, Ulusal Alerji ve Bulaşıcı Hastalıklar Enstitüsü’ne göndermiştir. $\mathrm{Bu}$ gelişme ile aşı geliştirme konusunda rekor kıran bir süreç yaşanmıştır.

Üsküdar

University

Journal

of Social

Sciences, 2021;

issue: 12 ,

$155-204$

\section{Grafik1: Tarihte Aşıların Geliştirilme Süresi}

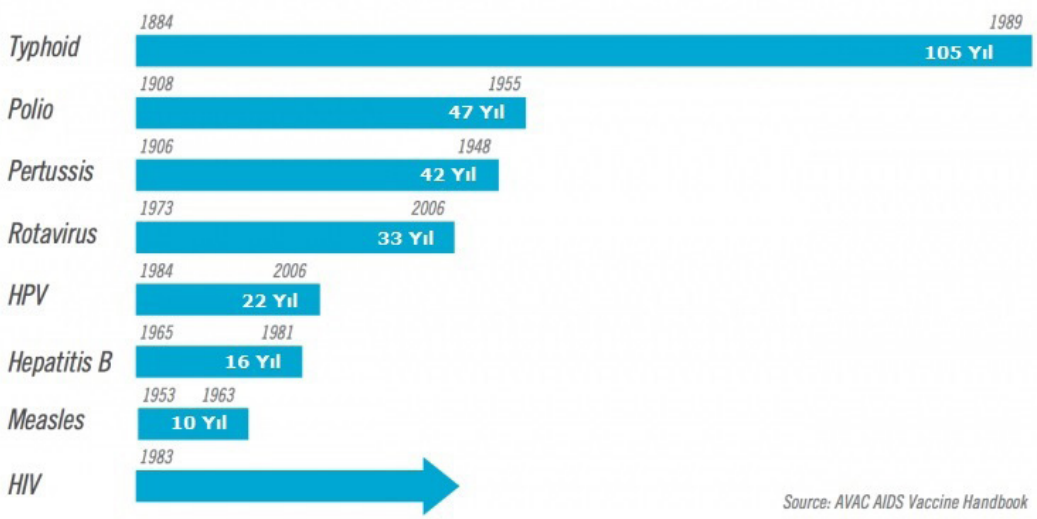

Kaynak: Avac.org. "Time to Develop a Vaccine," 2 Aralik 2020. https://www.avac.org/ infographic/time-develop-vaccine

Hastalıkların genetik yapısını bilmek, teşhis için çok önemlidir. 2020 Ocak ayının başlarında yayınlanan, Çin'in salgın merkezi Wuhan'dan bir

${ }^{42}$ WHO, "Vaccines and Immunization. WHO, 24 Kasım 2020, https://www.who.int/ health-topics/vaccines-and-immunization\#tab=tab_1." 


\section{Covid-19 Aşısının Lojistiğinde Karşılaşılan Zorluklar}

hasta izolatının genom dizisi analizi, viral izolasyondan sonra hızlı bir şekilde gerçekleştirilmiş, SARS-CoV-2 genomu, SARS-CoV-1'inkine yaklaşık $\% 80$ ve MERS-CoV'e $\% 50$ ve yarasa koronavirüsüne \%96 benzerlik bulunmuştur. ${ }^{43}$

Ülkeler veya laboratuvarlar COVID-19 aşı çalışmalarına aynı anda başlamamıştır. 2003 yılında ortaya çıkan Şiddetli Akut Solunum Sendromu (SARS) ve 2012 yılında ortaya çıkan Orta Doğu Solunum Sendromu (MERS) ile ilgili aşı çalışmaları yürüten şirketler ve ülkeler, tüm genom sekanslarının karşılaştırılması sonucunda SARS-cov-1 genomu ve MERScov genomu yüksek oranlı benzerlik gösteren COVID-19 etkeni SARScov-2'nin aşı çalışmalarında çok hızlı yol kat etmişlerdir. ${ }^{44}$

Dünya Sağlık Örgütü tarafından 10 Aralık tarihinde yayınlanan son bilgilere göre enfeksiyonu savuşturmak için bir dizi farklı teknik kullanan 200'den fazla aşı adayı mevcuttur. ${ }^{45} \mathrm{Bu}$ aşı adaylardan 162'si klinik öncesi hayvanlara uygulanma aşamasındadır. 59 Aşı araştırmacılar tarafından insanlar üzerinde klinik çalışmalar yapılmakta ve 16'sı testin son aşamalarına ulaşmış durumdadır. 2 aşı tam olarak kullanılma onayı alırken, 1 aşının çalışmaları durdurulmuştur.

${ }^{43}$ Peng Zhou et al., "A Pneumonia Outbreak Associated with a New Coronavirus of Probable Bat Origin,” Nature 579, no. 7798 (2020): 271; Colin D Funk, Craig Laferrière, and Ali Ardakani, "A Snapshot of the Global Race for Vaccines Targeting SARS-CoV-2 and the COVID-19 Pandemic," Frontiers in Pharmacology 11 (2020): 3.

${ }^{44}$ Roujian Lu vd., "Genomic characterisation and epidemiology of 2019 novel coronavirus: implications for virus origins and receptor binding," The Lancet 395, say1 10224 (22 Şubat 2020): 570; 2019, patients presenting with viral pneumonia due to an unidentified microbial agent were reported in Wuhan, China. A novel coronavirus was subsequently identified as the causative pathogen, provisionally named 2019 novel coronavirus (2019-nCoV Okyay, “Covid-19 Aşı Çalışmaları.”, 10 Aralık 2020, https://www.ttb.org. tr/kutuphane/covid19-rapor_6/covid19-rapor_6_Part24.pdf.

${ }^{45}$ WHO, "Draft landscape of COVID-19 candidate vaccines," 24 Kasim 2020, https:// www.who.int/ publications /m/item/draft-landscape-of-covid-19-candidate-vaccines. 


\section{Veli Ahmet ÇEviK}

\section{Şekil 2: Aşıların İlerleme Durumu}

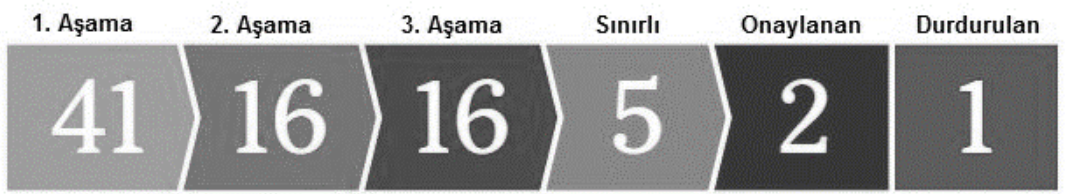

Kaynak: New York Times. "Covid-19 Vaccine Tracker: Latest Updates," 15 Aralik 2020, https://www.nytimes.com/interactive/2020/science/coronavirus-vaccine-tracker.html

Mevcut aşı öncülerinden bazıları, iki yeni nesil teknoloji platformundan yararlanmaktadır. Moderna ve BioNTech / Pfizer yeni bir RNA platformu kullanmaktadır. Hem AstraZeneca/Oxford hem de Johnson \& Johnson bir viral vektör aşısı üzerinde çalışmaktadırlar. Bu viral aşılar, bağışıklık

Üsküdar University Journal of Social Sciences, 2021; issue: 12 , $155-204$ tepkisini hızlandıran proteinler üretmek için insan hücrelerinin içine genetik materyal sağlayan canlı, zararsız virüsleri kullanmaktadır. ${ }^{46}$

\section{Tablo 1: Bazı Aşıların Özellikleri}

\begin{tabular}{|l|c|c|c|c|}
\hline Aşı Şirketleri & Teknik & Etki Oranı & Uygulama & Saklama \\
\hline Biontech/Pfizer & M-RNA & $\% 95$ & $2 \mathrm{Doz}$ & $-80^{\circ} \mathrm{C}$ \\
\hline Moderna & M-RNA & $\% 95$ & $2 \mathrm{Doz}$ & $-20^{\circ} \mathrm{C}$ \\
\hline Oxford/Astrazeneca & Viral Vektör & $\% 70$ & $2 \mathrm{Doz}$ & $2-8^{\circ} \mathrm{C}$ \\
\hline Sputnik V & Viral Vektör & $\% 95$ & $2 \mathrm{Doz}$ & $2-8^{\circ} \mathrm{C}$ \\
\hline Sinovac/Coronavac & Viral Vektör & $\% 97$ & $2 \mathrm{Doz}$ & $2-8^{\circ} \mathrm{C}$ \\
\hline
\end{tabular}

Kaynak: BBC. "Sinovac: Koronavirüs aşısı CoronaVac hakkında neler biliniyor," 4 Aralık 2020. https:// www.bbc.com/turkce/haberler-dunya-55162850

İngiliz-İsveç ilaç şirketi AstraZeneca ve Oxford Üniversitesi birlikte geliştirdiği aşı ile ilgili olarak 23 Kasım'da yapılan açıklamada, Birleşik Krallık ve Brezilya'da yapılan Faz 3 denemelerinin bir ara analizine

${ }^{46}$ Julia Belluz ve Umair Irfan, "AstraZeneca-Oxford Covid-19 vaccine: Why it's different - Vox,” 14 Aralik 2020, https://www.vox.com/21590994/oxford-vaccineresults-covid-19-astrazeneca-trial-pfizer-moderna. 
göre, dozların verildiği şekle bağlı olarak yüzde 62 ya da yüzde 90 etkili olduğunu duyurmuştur. ${ }^{47}$

İlaç üreticisi Moderna, 30 Kasım'da büyük bir araştırmadan elde edilen verilerin sonuçlarını açıklamış ve koronavirüs aşısının yüzde 94,1 etkili olduğunu duyurmuştur. Şirket, aşının acil kullanım için yetkilendirilmesi amacıyla Gıda ve İlaç İdaresine başvurduğunu ve onaylanması halinde Amerikalılar için enjeksiyonların erken bir zamanda başlayabileceğini açıklamıştır. Şirketin Aralık ayı sonunda 20 milyon doz üretme yolunda ilerlediğini ve 2021 'de üretimin 500 milyondan bir milyara ulaşacağını ifade edilmiştir. ${ }^{48}$

BioNTech, Ocak ayında bir aşı üzerinde çalışmaya başlayarak, Kasım ayı başlarında 3. Aşama denemelerinin sonuçlarının yüzde 90'ın üzerinde etkinlik sağladığını duyurmuştur. 2 Aralık'ta ilk kez İngiltere tarafından Pfizer/BioNTech aşısının yaygın kullanımını resmi olarak onaylanmıştır. ABD'de kullanımı için Amerikan Gıda ve İlaç Ajansı'na (FDA), aşısının acil kullanımına izin verilmesi için başvuru yapıldığını duyurmuştur. ${ }^{49}$

Çinli koronavirüs aşı üreticisi Sinovac Biotech, ilk olarak 2003 yılında bir SARS aşısının klinik denemelerine başlamış ve ilk olarak 2009'da domuz gribi aşısını piyasaya sürmüştür. Şirket koronavirüs aşısını, Çin'in koronavirüs salgınının merkez üssü Wuhan'ın karantina altına girmesinden kısa bir süre sonra, Ocak ayı sonlarında geliştirmeye başlamış ve üçüncü faz aşı çalışmalarını aralarında Türkiye, Brezilya ve Endonezya’nın da bulunduğu ülkelerde sürdürmektedir. Şirketin 18 Kasım'da yaptığı

${ }^{47}$ Astrazeneca, "AZD1222 vaccine met primary efficacy endpoint in preventing COVID-19,” 4 Aralık 2020, https://www.astrazeneca.com/media-centre/pressreleases $/ 2020 /$ azd1222hlr.html

${ }^{48}$ Denise Grady, "Moderna Is Applying for Emergency F.D.A. Approval for Its Coronavirus Vaccine - The New York Times," 4 Aralık 2020, https://www.nytimes.com/2020/11/30/ health/covid-vaccine-moderna.html.

${ }^{49}$ Biontech, "Press Releases," 4 Aralık 2020, https://investors.biontech.de/press-releases. 


\section{Veli Ahmet ÇEviK}

açıklamaya göre 700 kişiden gelen ilk sonuçlar aşının hızlı bir şekilde bağışılklık oluşturduğunu gösteriyor. ${ }^{50}$

\section{Tahsis}

Aşıların eşitliğine yönelik kamu taahhütlerine rağmen, ülkeler, nüfuslarını kapsama şanslarını artırmak için mümkün olduğu kadar çok aşı dozu satın almaya teşvik edilmektedir. Eşi görülmemiş derecede yüksek talep nedeniyle, birçok ülke kişisel koruyucu ekipman, mekanik ventilatörler ve COVID-19 hastalığı teşhisi gibi temel tıbbi malzemelere erişimde aşırı zorluklarla karşı karşıyadır. Tüm ülkeler gelişimsel veya ekonomik durumlarına bakılmaksızın mevcut olduklarında bu ürünlerin bir kısmına erişebilmelidir. $\mathrm{Bu}$ ilkenin gerçekleşmesi için, dünyanın

Üsküdar University Journal of Social Sciences, 2021; issue: 12 , $155-204$ objektif kriterlere dayalı erişim ve tahsis için açık, şeffaf ve geniş kabul görmüş bir çerçeveye ve mekanizmaya ihtiyacı vardır.

Kıt bulunan veya farklı amaca yönelik COVID-19 sağlık ürünlerine adil, eşit ve zamanında erişim sağlamak için görevlendirilen DSÖ Sekreterliği bu görevin tamamlanması için üç çıtı öngörmektedir:

1. COVID-19 için sağlık ürünlerine erişim ve bunların tahsisi için bir dizi kapsayıc ilke;

2. COVID-19 sağlık ürünlerine eşit ve adil erişim ve dağıtım sağlamak için küresel bir çerçeve;

3. Her ürün akışı için ilgili ortaklarla işbirliği içinde geliştirilen adil ve eşitlikçi tahsis mekanizmaları. ${ }^{51}$

\footnotetext{
${ }^{50}$ Eva Dou, "China coronavirus vaccine race is muddied by history of bribes at Sinovac," 15 Aralık 2020, https://www.washingtonpost.com/world/asia_pacific/coronavirus-vaccinechina-bribery-sinovac/2020/12/04/7c0 9ae68-28c6-11eb-9c21-3cc501d0981f_story. html.

${ }^{51}$ WHO, "WHO Concept for fair access and equitable allocation of COVID-19 health products," 24 Kasim 2020, https://www.who.int/docs/default-source/ coronaviruse/who-covid19-vaccine-allocation-final-working-version-9s ept. pdf?sfvrsn=e1d0376_6\&download=true.,
} 
DSÖ, Aşılara Küresel Erişim Programı (COVAX) aracılığıyla COVID-19 aşıları için adil tahsis mekanizmasını devreye sokarak, bir aşının güvenli ve etkili olduğu ve kullanım için izin verildiği zaman tüm ülkelerin başlangıçta azaltılmış miktarlarda da olsa, nüfus büyüklükleriyle orantılı dozlar almasını tavsiye etmektedir. Bu uygulamalar, her ülkenin en yüksek öncelikli nüfusu aşılayarak başlamasını sağlayacaktır.

İkinci aşamada, aşılar tüm ülkelere dağıtılmaya devam edilecek, böylece ek nüfus da ulusal önceliklere göre kapsanabilecektir.

Aşıların adil tahsisi aşağıdaki şekilde gerçekleşecektir: ${ }^{52}$

1. Tüm ülkeler nüfuslarının \%20'sini kapsayacak kadar yeterli miktarlara ulaşana kadar başlangıçta ülkelere dozların orantılı tahsisi

2. Nüfusun geri kalanını da kapsayacak şekilde genişletmek için bir takip aşamasının geliştirilmesi. Ciddi arz kısıtlamaları devam ederse, bir ülkenin COVID tehdidi ve güvenlik açığı dikkate alınarak ağırlıklı bir tahsis yaklaşımı benimsenecektir.

Covid 19 Aşıları Küresel Erişim Programı (COVAX), dünyadaki yüksek riskli nüfusu korumak için 2021'in sonuna kadar iki milyar doz sağlamayı hedeflemektedir. Kendi kendini finanse eden ülkeler farklı düzeylerdeki nüfus kapsamlarına göre aşıları satın alabilirler ancak COVAX’ın uzun vadedeki amacı, finanse edilen ülkelere nüfuslarının \%20'sini karşılamaya yetecek dozlar sağlamaktır. ${ }^{53}$

3 Aralık 2020 tarihinde Birleşmiş Milletler Genel Kurulu Covid-19’la Mücadele Özel Oturumunda dünya liderleri, aşıların adil dağılımını sağlamak için acil eylem talep etmiş, Genel Kurul Başkanı Volkan Bozkır

\footnotetext{
${ }^{52}$ Mark Eccleston-Turner and Harry Upton, "International Collaboration to Ensure Equitable Access to Vaccines for COVID-19: The ACT-Accelerator and the COVAX Facility," The Milbank Quarterly, (2021): 11.

53 Gavi the Vaccine Alliance, “The Gavi COVAX AMC Explained,” 5 Aralık 2020, www. gavi.org/vaccineswork/gavi-covax-amc-explained
}

Üsküdar Üniversitesi Sosyal Bilimler Dergisi, 2021; sayl: 12 , $155-204$ 


\section{Veli Ahmet ÇEViK}

aşılara adil ve eşit erişim sağlamak için uluslararası toplumun çok taraflı hareket etmesi gerektiğini söylemiştir. ${ }^{54}$

\section{Tablo 2: Ülkelerin Aşı Sipariş Adetleri}

\begin{tabular}{|l|r|r|r|r|r|r|}
\hline & $\begin{array}{r}\text { Oxford } \\
\text { Universitesi }\end{array}$ & $\begin{array}{c}\text { Pfizer/ } \\
\text { Biontech }\end{array}$ & Moderna & Sinovac & \multicolumn{1}{c|}{ Diğer } & \multicolumn{1}{c|}{ Toplam } \\
\hline Hindistan & 500.000 & & & & 1100.000 & $\mathbf{1 . 6 0 0 . 0 0 0}$ \\
\hline AB & 400.00 & 300.000 & 160.000 & & 725.000 & $\mathbf{1 . 5 8 5 . 0 0 0}$ \\
\hline ABD & 500.000 & 100.000 & 100.000 & & 310.000 & $\mathbf{1 . 0 1 0 . 0 0 0}$ \\
\hline Kanada & 20.000 & 20.000 & 56.000 & & 262.000 & $\mathbf{3 5 8 . 0 0 0}$ \\
\hline İngiltere & 100.000 & 40.000 & 5.000 & & 210.000 & $\mathbf{3 5 5 . 0 0 0}$ \\
\hline Endonezya & 100.000 & & & 128.000 & 125.000 & $\mathbf{3 5 3 . 0 0 0}$ \\
\hline Japonya & 120.000 & 120.000 & 50.000 & & & $\mathbf{2 9 0 . 0 0 0}$ \\
\hline Brezilya & 100.000 & & & 46.000 & 50.000 & $\mathbf{1 9 6 . 0 0 0}$ \\
\hline Meksika & 77.400 & 34.400 & & & 67.000 & $\mathbf{1 7 8 . 8 0 0}$ \\
\hline Türkiye & & & & 50.000 & & $\mathbf{5 0 . 0 0 0}$ \\
\hline
\end{tabular}

Kaynak: Launchandscalefaster.org. "COVID-19 Launch and Scale Speedometer," 5 Aralik 2020. https://launchandscalefaster.org/COVID-19

Aşıların son test aşaması olan Faz 3 seviyesine yaklaşmasıyla ülkeler sipariş yarışına başlamış ve birçok ülke siparişlerini tamamlamıştır. Her ne kadar Dünya Sağlık Örgütü, Birleşmiş Milletler ve diğer dünya liderleri tarafından aşıların adil dağıtımı vurgulansa da uygulamada çok da adil olunmamıştır. Grafik 2'de görüldüğü üzere Kanada nüfusunun yaklaşık 10 katı bir aşı siparişi vermiştir. Avustralya ve İngiltere 5 kat, $A B D$ ve $A B$ yaklaşık 3 kat aşı siparişi vermiştir.

\footnotetext{
${ }^{54}$ United Nations, "With More Than 1.5 Million Lives Lost to COVID-19, World Leaders in General Assembly Demand Urgent Action to Guarantee Equitable Distribution of LifeSaving Vaccines; Meetings Coverage and Press Releases,” 5 Aralık 2020, https:/ /www. un.org/press/en/2020/ga12293.doc.htm.
} 


\section{Grafik 2: Ülkelerin sipariş ettikleri Aşıların Nüfuslarına Olan Oranları}

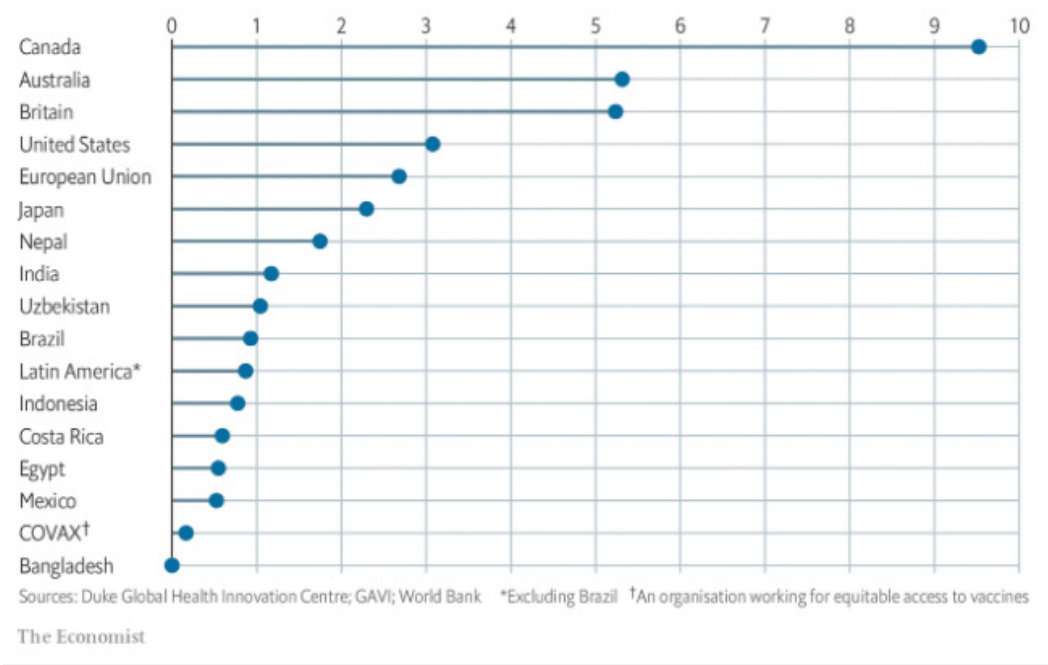

Kaynak: The Economist. "Rich countries grab half of projected covid-19 vaccine supply," 29 Kasim 2020. https://www.economist.com/graphic-detail/2020/11/12/rich-countriesgrab-half-of-projected-covid-19-vaccine-supply

Kasım 2020 itibariyle birçok ülke, 13 aşı üreticisinden aşılar piyasaya sürülmeden önce toplam 7,48 milyar doz Covid-19 aşısı için satın alma taahhüdü vermiştir. Bu dozların yarısından fazlası, dünya nüfusunun \% 14 ünü temsil eden yüksek gelirli ülkelere gideceği tahmin edilmektedir..$^{5 s}$
Üsküdar Üniversitesi Sosyal Bilimler Dergisi, 2021; sayl: 12 , $155-204$

${ }^{55}$ Anthony D So and Joshua Woo, "Reserving Coronavirus Disease 2019 Vaccines for Global Access: Cross Sectional Analysis,” Bmj 371, say1: 371, (2020): 1. 


\section{Veli Ahmet ÇEviK}

\section{Grafik 2: Ülke Gelir Düzeyine Göre Satın Alınan COVID-19 Aşı Dozları Yüzdesi}

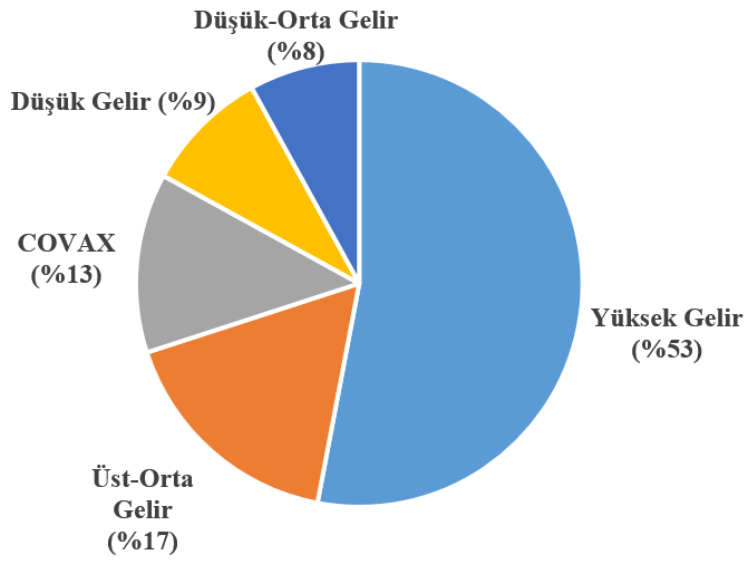

Kaynak: Duke Global Health Innovation Center, "Vaccine Procurement" 14 Nisan 2021, https://launchandscalefaster.org/covid-19/vaccineprocurement of Social Sciences, 2021; issue: 12 , $155-204$

Dünya Sağlık Örgütü Başkanı’nın Mart ayı başlarında yaptığı açıklamada, COVID-19 aşılarının dünya çapında "adaletsiz dağıtımının" "her geçen gün daha garip” hale geldiğini söyleyerek, daha fazla dayanışma çağrılarını yenilemiştir. ${ }^{56}$

Aşı üreticisi konumundaki ülkeler kendi aşı ihtiyaçlarını öncelemeleri nedeniyle "aşı milliyetçiliği”" kavramı ortaya çıkmıştır. Ülkelerin kendi vatandaşlarına kullanım için daha fazla aşı tedariki tutma planları (Grafik 3), DSÖ başkanının zengin ve fakir ülkeler arasında "garip" bir arz uçurumu olarak adlandırdığı durumu daha da kötüleştirmekte ve Covid-19 salgınıyla mücadelede küresel dayanışma olasılığına bir darbe daha vurmaktadır. İlk olarak 24 Mart tarihinde Avrupa Birliği, ülke içindeki

\footnotetext{
${ }^{56}$ Euronews.com, "Global COVID Vaccine Inequality 'becoming More Grotesque Every Day,' WHO Warns | Euronews,” 12 Nisan 2021, https://www.euronews.com/2021/03/22/ global-covid-vaccine-inequality-becoming-more-grotesque-every-day-who-warns.
} 
arz sıkıntısını hafifletmek için İngiltere'ye ve diğer ülkelere yapılan ihracatı ciddi şekilde azaltacak yeni acil durum kuralları getirdiğini duyurmuştur. Aynı tarihte Hindistan hükümeti yetkilileri yerel talebi önceliklendirmek için, Hindistan Serum Enstitüsü tarafindan yapılan Oxford/AstraZeneca aşılarının ihracatını durdurduklarını açıklamıştır. ${ }^{57}$

\section{Grafik 3: 29 Mart 2021 İtibariyle Küresel Aşı Üretimi}

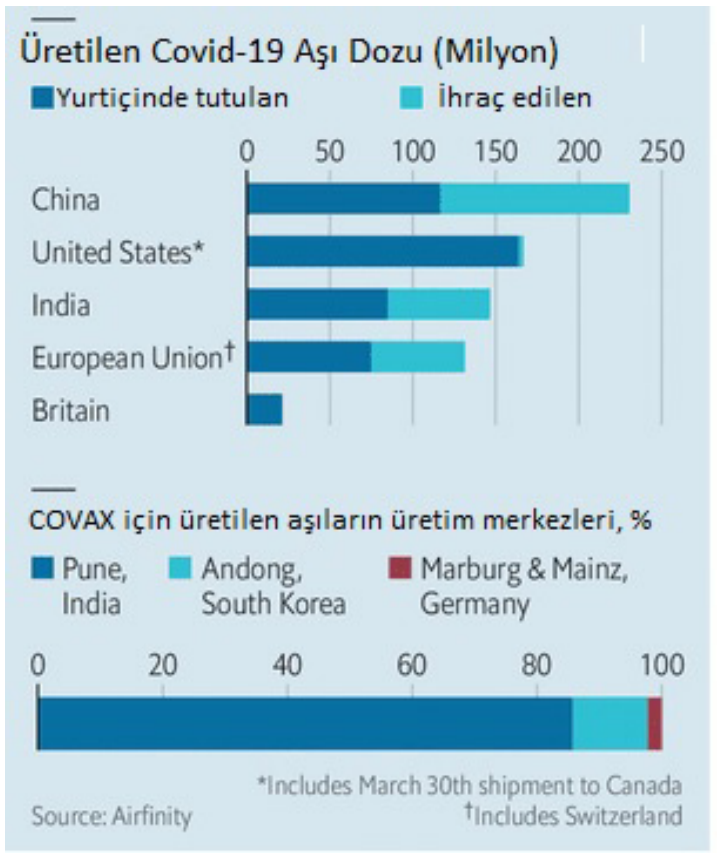

Üsküdar

Üniversitesi

Sosyal Bilimler

Dergisi, 2021;

sayl: 12 ,

$155-204$

Kaynak: The Economist, "Almost One Billion Doses of Covid-19 Vaccines Have Been Produced," 12 Nisan 2021, (Uyarlanmıştrr) https://www.economist.com/ international/2021/03/31/almost-one-billion-doses-of-covid-19-vaccines-have-beenproduced

${ }^{57}$ Chris Kay, Jason Gale, and Michelle Cortez, "Vaccine Nationalism in India, Europe Keep World's Poor Waiting," 12 Nisan 2021, https://www.bloombergquint.com/ coronavirus-outbreak/curbs-by-world-s-biggest-vaccine-exporter-to-hit-poorest-nations 


\section{Veli Ahmet ÇEviK}

İhracat yasakları küresel aşı üretimine zarar verecektir. Örneğin, Pfizer aşısı 19 ülkedeki 86 tedarikçiden 280 bileşen içermektedir..$^{58}$ Tüm bileşenlerin hiçbir tedarikçi ülkede engele takılmadan üretim hatlarında buluşması salgının durdurulması için önem arz etmektedir. Diğer bir risk ise, Amerika'nın hammadde ve ekipman üzerindeki ihracat kontrolleridir. The Economist'e göre, ABD'nin 37 kritik ürünü tedarik etmemesi durumunda Hindistan'da ayda en az 160 milyon doz Covid aşısı üreten hatlar, yakında durma noktasına gelecektir. ${ }^{59} 16$ Nisan'da dünyanın en büyük aşı üreticisi Hindistan Serum Enstitüsü’nün Başkanı Adar Poonawalla, Twitter hesabından ABD Başkan’ı Joe Biden’a yazdığı “...Bu virüsü yenmek ve aşı üretiminin hızlanabilmesi için $\mathrm{ABD}$ 'den hammadde

Üsküdar University Journal of Social Sciences, 2021; issue: 12 , $155-204$ ihracat ambargosunu kaldırmasını rica ediyorum..." "o tweetle, hammadde ihracat ambargosunu kaldırmasını talep etmiştir.

Aşılara erişimde güçlük çekebilecek az gelişmiş ülkelere aşı tedarikini sağlamak için 2020 yllında kurulan COVAX’a, yaklaşık 192 ülke katılmış ve her birine halkının \%20'sini aşlamaya yetecek kadar aşı sözü verilmiştir. Ancak 24 Mart'ta, COVAX'ın aşı malzemelerinin \% 86'sını sağlayan Hindistan'ın aşı ihracatını geçici olarak durdurması söz konusu ittifakın hedeflerine büyük bir darbe vurmuştur. ${ }^{61}$

58 Marie O’Halloran, “Taoiseach Warns against Global Interruption of Vaccine Delivery," 6 Mayıs 2021, https: //www.irishtimes.com/news/politics/ taoiseach-warns-against-global-interruption-of-vaccine-delivery-1.4518904.

${ }^{59}$ The Economist, "American Export Controls Threaten to Hinder Global Vaccine Production" 6 Mayıs 2021, https://www.economist.com/science-and-technology/2021/04/22/ american-export-controls-threaten-to-hinder-global-vaccine-production ${ }^{60}$ Adar Poonawalla, A. Twitter post. 16 Nisan 2021, 11:46 a.m., https://twitter.com/ adarpoonawalla

${ }^{61}$ The Economist, "Almost One Billion Doses of Covid-19 Vaccines Have Been Produced” 12 Nisan 2021, https://www.economist.com/international/2021/03/31/ almost-one-billion-doses-of-covid-19-vaccines-have-been-produced. 


\section{Covid-19 Aşısının Lojistiğinde Karşılaşılan Zorluklar}

Ayrıca kısıtlı sayıdaki aşıların dağıtımı diplomasiye yansımış, bazı ülkeler aşıları diplomatik araç olarak kullanmaya başlamışlardır. Örneğin İsrail, Suriye ile tutuklu bir İsrail vatandaşının serbest bırakılması karşıllğında ülkeye Rus aşıları sağlamak için bir anlaşma yapmıştır. ${ }^{62}$

Eğer bu salgının tüm dünyada sürü bağışıklığı kazanılarak durdurulması amaçlanıyorsa, önemli olan aşıyı erken elde etmek değil eşit seviyede bir aşılama programı dünya sağlığı için daha sürdürülebilir olacaktır.

\section{Dağıtım}

Her geçen gün, koronavirüs için etkili bir aşı geliştirmenin ve adil dağılımını sağlamanın önemine atıfta bulunan "Herkes güvende olana kadar kimse güvende değildir” ifadesi anlam kazanmaktadır. Bugünlerde, yüzlerce ayrı aşı adayı geliştirilmekte ve onlarcası şu anda klinik deneme aşamasındadır.

Uluslararası Hava Taşımacılığı Birliği (IATA), dünyadaki her erkek, kadın ve çocuk için ikişer doz olacak şekilde 14 milyar doz aşının tedarik edilmesi iki yıl sürecek olan hava nakliyesi için, 110 ton kapasiteli Boeing 747 kargo uçağı ile 8.000 sefere eşdeğer bir operasyonun gerekli olacağını tahmin etmektedir. ${ }^{63}$ DHL ve McKinsey şirketleri tarafından yapılan yakın tarihli bir çalışma ise söz konusu taşıma için 15.000 uçuşa gerek olacağını tespit ederken, tıbbi personel için şırıngalar ve koruyucu ekipman da dahil edilmesi durumunda kargo alanı gereksinimini artacağı vurgulanmıştır. ${ }^{64}$

${ }^{62}$ Patrick Kingsley, "Israel Secretly Agrees to Fund Vaccines for Syria as Part of Prisoner Swap - The New York Times," 12 Nisan 2021, https://www.nytimes.com/2021/02/20/ world/middleeast/israel-syria-prisoner-swap-vaccines.html.

${ }^{63}$ IATA, “The Time to Prepare for COVID-19 Vaccine Transport is Now," 14 Arallk 2020, https:// www.iata.org/en/pressroom/pr/2020-09-09-01/.

${ }^{64} \mathrm{DHL}$, "Delivery of COVID-19 vaccine: DHL study shows how public and private sector can partner for success,” 14 Aralık 2020, https: / / www.dpdhl.com/en/media-relations/ press-releases/2020/delivery-covid-19-vaccine-dhl-study-shows-how-public-and-privatesector-can-partner-for-success.html. 


\section{Veli Ahmet ÇEviK}

\section{Şekil 3: Aşı Soğuk Zincir Uygulama Aşamaları}

Üsküdar

University

Journal of Social

Sciences, 2021;

issue: 12 ,

155-204

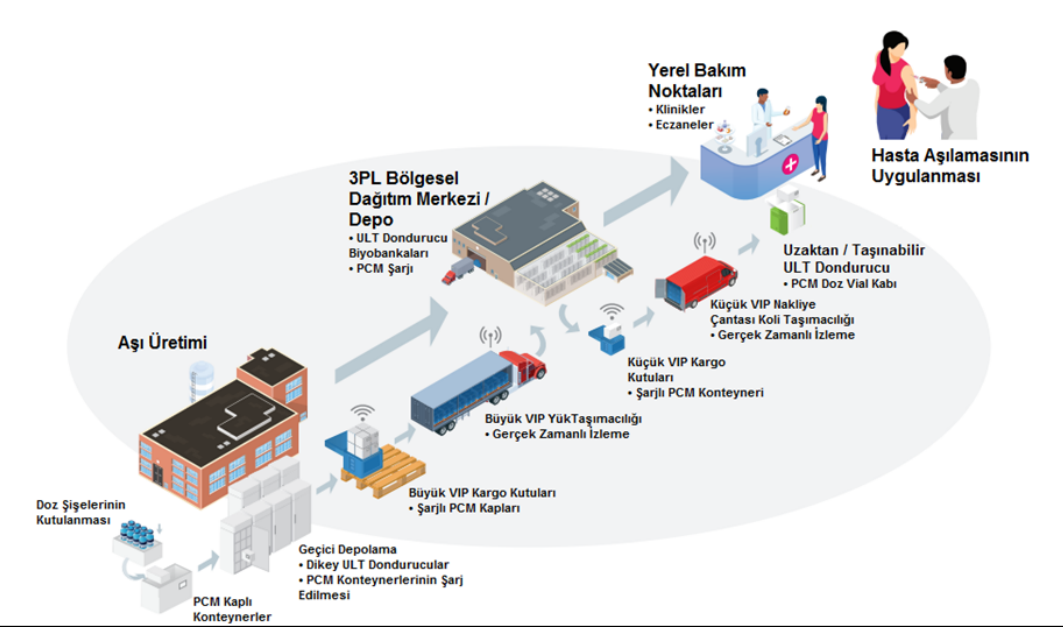

Kaynak: Stirlingultracold.com. "Unmatched $80^{\circ} \mathrm{C}$ Storage Advantages Across the COVID-19 Vaccine Cold Chain," 5 Aralik 2020, https://www.stirlingultracold.com/wpcontent/uploads/2020/09/C-19_Vaccine-Distribution_White-Paper_Stirling_Ultracold. $p d f$

Dağıtım operasyonu, aşıların uzaktaki üretim alanlarından depolar, kargo terminalleri, havaalanları ve son depolama noktaları aracılığıyla tıp ekiplerine götürülmesinin her aşamasında riskli bir lojistik eylemi gerektirmektedir (Şekil 3). Soğutma ekipmanındaki arızalar, nakliye gecikmeleri, bozuk ambalajlar veya diğer aksilikler binlerce dozu işe yaramaz hale getirebilecektir. ${ }^{65}$ Dünya Sağlık Örgütü, sıcaklık kontrolü, lojistik ve sevkiyatla ilgili sorunlar nedeniyle her yıl küresel olarak aşıların \%50'sinden fazlasının boşa gittiğini tahmin etmektedir. ${ }^{66}$

${ }^{65}$ Elaine Chen, "From 'Freezer Farms' to Jets, Logistics Operators Prepare for a Covid-19 Vaccine," 11 Aralık 2020, https: / /www.wsj.com/articles/from-freezer-farms-to-jetslogistics-operators-prepare-for-a-covid-19-vaccine -11598639012

${ }^{66} \mathrm{WHO}$, "Monitoring vaccine wastage at country level Guidelines for programme managers Immunization, Vaccines and Biologicals," 6 Aralık 2020, www.who.int/vaccines-documents/. 


\section{Kargo kapasitesi}

Hava yoluyla taşınan tüm yüklerin yaklaşık yarısı, kullanımda olan yaklaşık 2.000 kargo uçağının yanı sıra tipik olarak dünyadaki 22.000 normal yolcu uçağının kargo bölümünde taşınmaktadır. Ancak salgının havacılık sektörünü vurmasıyla dünya havacılık filosunun yaklaşık \%30 u yere indirilmiştir. Diğer yandan Covid-19 nedeniyle artan çevrimiçi Noel alışveriş çılgınlığı zirveye ulaştığında, büyük girişimin kargo taşıyıcıları için yoğun bir zamanda başlaması güçlük oluşturacaktır.

IATA, ilaç sevkiyatlarının hâlihazırda küresel hava kargo hacminin yaklaşık \%1,9'unu oluşturduğunu ve Covid-19 aşılarının eklenmesinin bu payı ikiye katlayabileceğini açıklamıştır. Ancak kargo uçaklarında taşınan eşyaları soğutmak için ne kadar kuru buz taşınabileceğine ilişkin yasal kısıtlamalar nedeniyle çok soğuk kargoların taşıma kapasiteleri sınırlandırılacaktır. IATA tehlikeli maddeler yönetmeliğine göre kuru buz taşıması özel sınırlandırmalara tabi tutulmuştur. Ultra dondurulmuş aşı, palet başına 276 kg'a kadar kuru buz gerektirebileceğinden şu anda uçuş başına kabul edilebilir kuru buz miktarı, uçak tipine bağlı olarak $1000 \mathrm{~kg}$ ila $15000 \mathrm{~kg}$. arasındadır. Uçuş başına palet sayısı, daha düşük dereceli uçaklar için 4 palete kadar azaltılabilecektir. ${ }^{67} \mathrm{Bu}$ aralıklar, nihayetinde belirli alanlara taşınabilen aşı miktarını sınırlayacak ve kapasite arz ve talebinde daha büyük bir boşluk yaratacaktır.

Pfizer-BioNTech aşısı diğer aşıların operasyonundan farklı olarak fazladan bir zorluğa sahiptir. Söz konusu aşı, Antarktika'daki kış şartlarından daha soğuk olan $-70^{\circ} \mathrm{C}$ sıcaklıkta taşınması gerekmekte ve şirketler, her aşı sevkiyatının yerini ve sıcaklığını izlemek için GPS özellikli termal sensörleri kullanmayı planlamaktadır. ${ }^{68}$

${ }^{67}$ Andrea Gruber, "Global Distribution and Flow of Vaccines Throughout the Supply Chain,” 11 Aralık 2020, https://www.iata.org/contentassets/ a80dd566681a4adfabccc43041abdcfb/transport-of-vaccines-webinar-2-slides.pdf ${ }^{68}$ Pfizer, "COVID-19 Vaccine U.S. Distribution Fact Sheet," 6 Aral1k 2020, https:// www.pfizer.com/news/hot-topics/covid_19_vaccine_u_s_distribution_fact_sheet 


\section{Veli Ahmet ÇEViK}

3. Aşama denemelerine kadar ilerleyen üç aşıdan ikisi, Moderna ve Pfizer-BioNTech, sabit bir derin dondurucuda tutulmalıdır. Pfizer, aşısının $-80^{\circ} \mathrm{C}$ kadar düşük sıcaklıklarda saklanmasını beklerken, Moderna $>$ nın $-20^{\circ} \mathrm{C}$ sicaklikta tutulmasi gerekecektir. AstraZeneca ve Oxford Üniversitesi tarafindan geliştirilen bir diğer önde gelen aşının soğuk tutulması ancak dondurulmaması gerektiği bildirilmiştir.

Günümüzde çok az aşı üreticisi, üçüncü taraflojistik (3PL) sağlayıcıları, sağlık hizmetleri tesisleri veya eczaneler, aşıları -80 C’ye kadar düşük sıcaklıklarda sürekli olarak depolama ve taşıma kapasitesine sahiptir. 2011 yılında soğuk zincir arızaları nedeniyle beş ülkede 2,8 milyon doz aşının kaybedildiği ve Nijerya'da buzdolaplarının \%41'inin işlevsel olmadığ Dünya Sağlık Örgütü tarafından rapor edilmiştir. ${ }^{69} \mathrm{Bu}$ nedenle, bu

Üsküdar University Journal of Social Sciences, 2021; issue: 12 , $155-204$ muazzam görevi yerine getirmek için, bu kuruluşların Çok Düşük Sıcaklık (ULT) soğuk zincir kapasitesini uçtan uca hızla artırarak aşıları güvenli bir şekilde depolaması ve yüz milyonlarca insana ulaştırması gerekmektedir.

Aşıların nakliye sırasında güvenli kalmasını sağlamak ve hızlı bir şekilde taşımak için Pfizer, aşıyı ultra soğuk sıcaklıklarda 10 güne kadar tutabilen ve 1.000 ile 5.000 doz kapasiteli yeni bir taşıma kabı tasarlamıştır. (Şekil 4)

Pfizer, kuru buzla paketlenen ve GPS ile takip edilen çanta boyutundaki kutular sayesinde nakliye sırasında kullanılan daha büyük, sıcaklık kontrollü konteynerleri kullanmayacaktır. Uçaklar veya kamyonlar, standart soğutmalı konteynerleri beklemek zorunda kalmayacağından şirkete, aşıları daha hızlı nakletmesi için daha fazla esneklik sağlayacaktır. ${ }^{70}$

\footnotetext{
${ }^{69}$ WHO, "Immunization Supply Chain And Logistics," 6 Aralık 2020, https://www. who.int/immunization/call-to-action_ipac-iscl.pdf

${ }^{70}$ Costas Paris ve Jared S. Hopkins, "Pfizer Sets Up Its 'Biggest Ever' Vaccination Distribution Campaign,” 11 Aralık 2020, https://www.wsj.com/articles/ pfizer-sets-up-its-biggest-ever-vaccination-distribution-campaign-11603272614.
} 


\section{Şekil 4: Ultra Soğuk Sıcaklıklarda Aşı Taşıma Kapları}

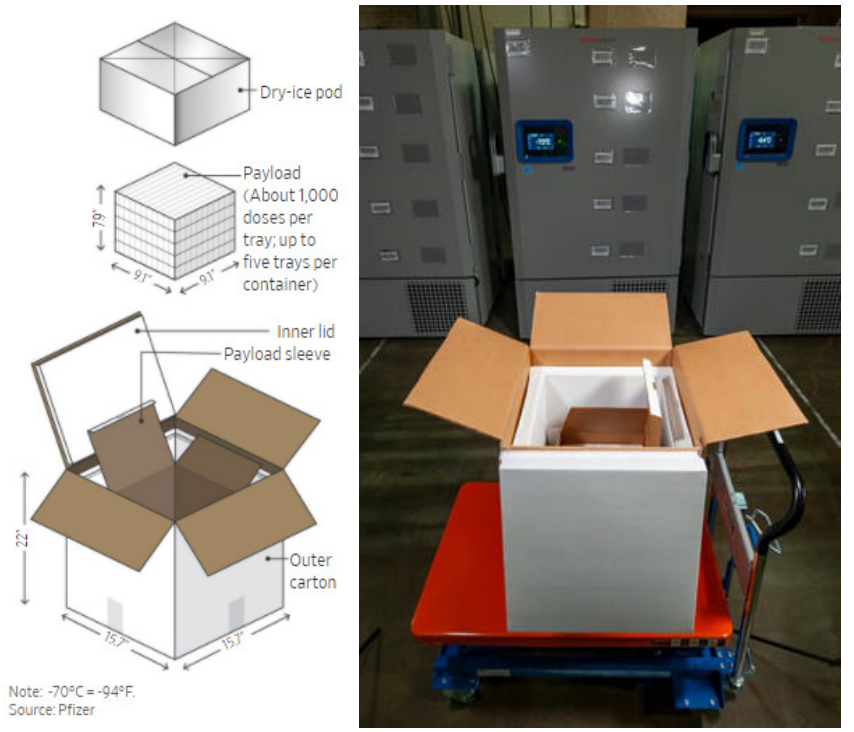

Kaynak: Paris, Costas, ve Jared S. Hopkins. "Pfizer Sets Up Its 'Biggest Ever' Vaccination Distribution Campaign," 11 Aralik 2020, https://www.wsj.com/articles/pfizer-sets-up-its-

Üsküdar Üniversitesi Sosyal Bilimler Dergisi, 2021; sayl: 12 , $155-204$

\section{Çalınma ve Siber Saldırılar}

Taşınan Varlıkları Koruma Derneği, Koronavirüs karantinaları Avrupa, Orta Doğu ve Afrika bölgesinde kaldırılmaya başladıkça, üreticiler ve lojistik hizmet sağlayıcılarını, tedarik zincirlerindeki kargo hırsızlıklarında öngörülen önemli bir artıştan korumaya hazırlıklı olması konusunda uyarmışır.. ${ }^{71}$ TAPA raporlarına göre, 1 Mart-31 Mayıs 2020 tarihleri arasında tedarik zincirlerinde değeri 16,4 milyon €'dan fazla olan,

\footnotetext{
${ }^{71}$ TAPA, “TAPA: $€ 10$ Million in Product Losses In October As Major Cargo Thefts In Emea Average €686,300,” 11 Aralık 2020, https://tapa.memberclicks.net/assets/docs/2020 VIGILANT_WEB/TAPA\%20Vigilant\%20e-Magazine\%20-\%20November\%202020\% 20 Issue.pdf
} 


\section{Veli Ahmet ÇEViK}

İspanya'da iki milyon yüz maskesi, Birleşik Krallık'ta spor malzemeleri ve Kenya'da cep telefonları dahil olmak üzere 400 'den fazla ürün hırsızlğg kaydedilmiştir. Bunların yanı sıra tedarik zincirlerindeki siber suçların sayısında da artış yaşanmaktadır. Bilgisayar korsanları 2 Aralık 2020'de ABD, Birleşik Krallık ve Güney Kore'de Covid-19 tedavileri üzerinde çalışan en az altı ilaç şirketini hedef alarak aşılara ait bilgileri yasal olmayan yollarla elde etmeye çalışmışlardır. Kısa süre sonra Avrupa Parlamentosu'na bağlı Avrupa İlaç Kurumu’ndan (EMA) yapilan açıklamada, Covid-19 aşısına iliş̧kin verilere yönelik siber saldırı düzenlendiği duyurulmuştur. ${ }^{22}$

\section{Son Kilometre Teslimatı}

Üsküdar University Journal of Social Sciences, 2021; issue: 12 , $155-204$

Aşıların teslimatı sadece havayollarıyla ilgili yapılmayacaktır. Aşının kırsal alanlara ulaştırılması için arabalar, otobüsler, kamyonlar, motosikletler, bisikletler ve hatta yük hayvanları gerekebilecektir. Bazı yerlerde yaya olarak taşınması da gerekebilir. Aşıların üretimi dünya üzerindeki sayılı merkezlerde gerçekleştirilmektedir. $\mathrm{Bu}$ merkezlerin bulunduğu ülkelere ve yakın şehirlere aşılar karayolu ile taşınırken, diğer ülkelere havayolu ile taşınacaktır.

Aşağıdaki grafik, dünya genelindeki çoğu ülkenin, nüfus büyüklüğü söz konusu olduğunda Kategori B ve C'ye girdiğini açıkça göstermektedir.

\footnotetext{
${ }^{72}$ EMA, "Cyberattack on the European Medicines Agency," 11 Aralık 2020, https://www. ema.europa.eu/en/ news/cyberattack-european-medicines-agency.
} 


\section{Grafik 4: Ülkelerin Nüfus Sayısına Göre Sınıflandırılması}

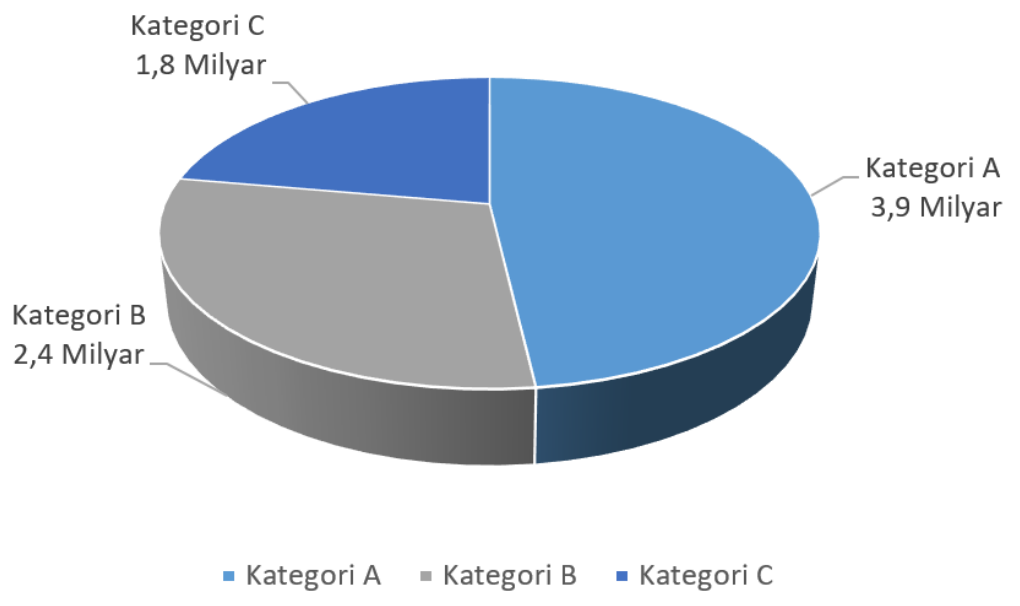

Kaynak: Europhia Consulting. "Key Transport Challenges In Covid-19 Vaccine Distribution," 12 Aralik 2020, https://europhia.com/covid-19-supply-chain

$B$ ve $C$ kategorilerine giren ülkelerde, aşıların, yerel üretime güvenmek yerine dünyanın diğer bölgelerinden hava kargo ile taşınması olasılığı yüksek olduğundan, hava taşımacılığı kapasitesi, dağıtım ve güvenlik açısından daha fazla dikkat gerekecektir.

\begin{tabular}{|l|c|}
\hline Kategori & Ülkeler \\
\hline Kategori A & Amerika Birleşik Devletleri, Çin, Hindistan, Rusya, Brezilya, AB Ülkeleri \\
\hline Kategori B & $\begin{array}{c}\text { Orta Büyüklükteki Ülkeler, } \\
\text { Örneğin; Endonezya, Japonya, Nijerya, Suudi Arabistan, İran, Türkiye, } \\
\text { Mısır ve diğerleri }\end{array}$ \\
\hline Kategori C & 50 Milyona kadar nüfusa sahip daha küçük ülkeler \\
\hline
\end{tabular}

Ancak Kategori A'daki ülkeler, şu anda yerel olarak aşı ürettikleri için karayolu taşımacılı̆̆ı dağıtım planlamasına daha fazla odaklanmaları gerekecektir. 


\section{Veli Ahmet ÇEvik}

\section{Aşı karşıtlığı}

Aşı tereddütleri aşıların kendisi kadar eskidir. 1798'de İngiliz Doktor Edward Jenner, çiçek hastalığına karşı bağışıklık kazandırdığı çiçek aşısını bulduğunda bazı insanlar, inek çiçeği aşısının doğal olmadığını ve bir hayvandangeldiğiiçinkötübirşeyolduğunu düşünüyordu. Kimileri, sağlıklı bir insanı kasıtlı olarak enfekte etmenin etiğini sorgulamış, Hindistan'da bazı Hindular kutsal kabul ettikleri ineklerden elde edilen materyali kullandığı için aşıyı istememişlerdir. ${ }^{73}$ Yakın zamanlı aşılara karşı direnişin temelleri ise, yirmi yıldan fazla bir süre önce başlayan bir aşı karşıtlı̆̆ hareketinde yatmaktadır. 1998'de Andrew Wakefield ve arkadaşları, önde gelen bir tıp dergisi olan İngiltere merkezli The Lancet'de otizm ve aşılar arasında bir bağlantı kurduğunu iddia eden bir çalışma yayınlamış ancak

Üsküdar University Journal of Social Sciences, 2021; issue: 12 , $155-204$ çalışma kusurlu bulunarak dergi tarafından geri çekilmiştir. ${ }^{74}$ Wakefield yaptığı çalışmadan pişmanlık duymamış, tıbbi ruhsatının iptal edilmesine rağmen, aşılar ve otizm arasında nedensel bir bağ kurmaya devam etmiştir. Yaşanan bu gelişmeler çocuk aşılarının güvenliğinden endişe duyan ebeveynleri harekete geçirmiştir.

Dijital Nefretle Mücadele Merkezi'ne göre koronavirüs salgını, 2020 yılının başından bu yana sekiz milyon takipçi kazanan aşı karşıtlı̆̆ hareketi için verimli bir zemin oluşturmuştur. ${ }^{75}$ Merkezin raporlarına göre aşı karşıtı grup, 31 milyonu Facebook'ta ve 17 milyonu YouTube'da olmak üzere sosyal medyada 58 milyon takipçiye ulaşmış ve yaklaşık 1 milyar dolarlık gelire sahip olmuştur. Bu rakamlar, kamuoyunun tedirgin olduğunu ve yanlış yöne giderse aşının piyasaya sürülmesini tehdit

73 Tom Standage, "Send for the Orphans: How the Smallpox Vaccine Crossed the Globe ” 12 Nisan 2021, https://www.economist.com/1843/2021/04/08/ send-for-the-orphans-how-the-smallpox-vaccine-crossed-the-globe

${ }^{74}$ A. J. Wakefield vd., "Retracted: Ileal-lymphoid-nodular hyperplasia, non-specific colitis, and pervasive developmental disorder in children," Lancet 351, sayı 9103 (28 Şubat 1998): 637-41,

${ }^{75} \mathrm{CCDH}$, “The Anti-Vaxx Industry How Big Tech powers and profits from vaccine misinformation 2," 11 Aralık 2020, https://www.counterhate.co.uk/anti-vaxx-industry 
edebileceğini göstermektedir. Salgını durdurmak için, ABD’nin önde gelen bulaşıcı hastalıklar yetkilisi Dr. Anthony Fauci, dört kişiden en az üçünün, tercihen nüfusun yüzde 85 'inin aşı olması gerektiğini ifade ederek, "İnsanların yüzde 50'si aşı olmazsa, önemli bir sağlık sorununuz var" şeklinde açıklama yapmıştır. ${ }^{76}$

Sosyal medyada dolaşan yanlış veya doğrulanmamış bilgilerden ve aşıların bu kadar çabuk geliştirilmesinden dolayı bazı insanlar aşıların güvenli olmayabileceğinden endişe duymaktadır. Çeşitli siyasi liderlerden gelen karışık mesajlar da bu şüpheye katkı yapmıştır.

\section{Tablo 3: "Aşı Bulunursa Yaptırır Mısın” Anketine Verilen Olumlu Cevapların Oransal Değişimi}

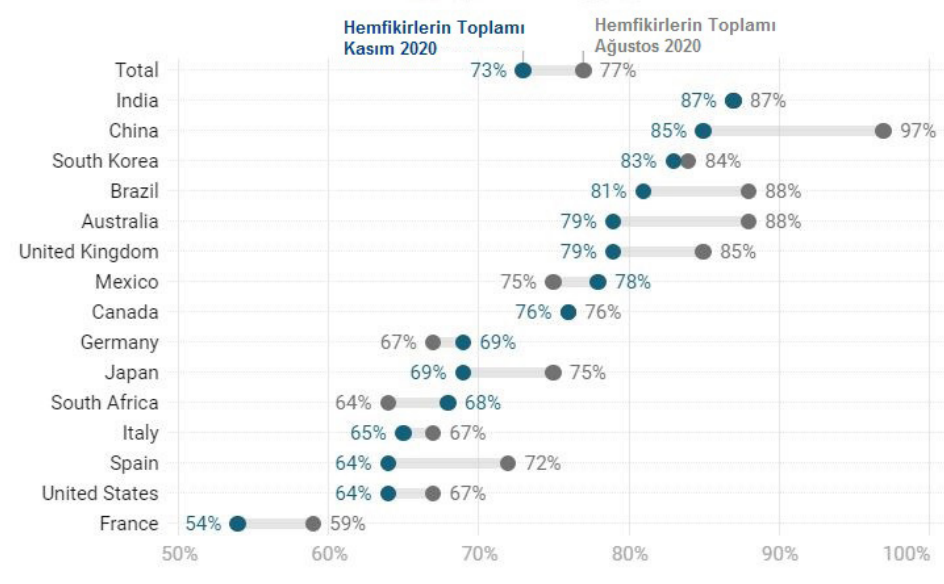

Üsküdar

Üniversitesi

Sosyal Bilimler

Dergisi, 2021;

sayl: 12 ,

$155-204$

Base: 18,526 online adults aged $16-74$ across 15 countries

Chart: Ipsos · Source: Global Advisor * Get the data - Created with Datawrapper

Kaynak: IPSOS. "COVID-19 vaccination intent is decreasing globally," 14 Aralik 2020, https://www.Ipsos.com/en/global-attitudes-covid-19-vaccine-october-2020

${ }^{76}$ Fred Guterl, "Vaccines Won't Stop the Pandemic Unless at Least 50 Million Skeptical Americans Change Their Minds,” 29 Kasım 2020, https://www.newsweek. com/2020/11/27/vaccines-wont-stop-pandemic-unless-least-50-million-skepticalamericans-change-their-minds-1549274.html 


\section{Veli Ahmet ÇEViK}

Kasım ayında Dünya Ekonomik Forumu ile IPSOS Araştırma Merkezi'nin ortaklaşa yürüttügü, 15 ülkeden 18.000'den fazla yetişkinin katıldığı yeni bir ankette, katılımcıların \%73'ü COVID-19 aşısı olacaklarını söylemişlerdir. Sonuçlar, üç ay öncesine göre aşı olma niyetlerinde yüzde dört puanlık bir düşüşü göstermektedir. Haziran 2020'de, COVID-19 aşısının kabulünü etkileyen faktörleri belirlemek için 19 ülkede 13.426 kişiyle anket yapan bir grup araştırmacının sonuçlarına göre, katılımcıların \%71,5'i COVID-19 aşısı olma ihtimalinin çok veya aşıyı bir şekilde olacağını ve \%61,4’ü işverenlerinin tavsiyesini kabul edeceklerini bildirmişlerdir.77 Sosyal medya şirketi Facebook, 3 Aralık 2020'de sağlıkla ilgili yanlış bilgilerle ilgili politikalarını sıkılaştırarak, Covid-19 aşıları hakkındaki yanlış iddiaları kaldırmaya başlayacağını açıklamıştır.78

Üsküdar University Journal of Social Sciences, 2021; issue: 12 , $155-204$

\section{Sonuç}

$\mathrm{Bu}$ çalışmada soğuk zincirin uygulama alanlarından olan aşı lojistiğindeki karşılaşılan güçlükler araştırılmıştır. Aşıların bulunmasının ardından küresel çapta ilk kez aynı anda aşılanmaya ihtiyaç duyulması aşılama sürecinin önemini ortaya çıkartmıştır. Literatürde aşılama süreçleri, ilgili bilimsel alanlara göre ayrı ayrı değerlendirilmiş ancak dünya nüfusunun aynı anda aşılara erişmeye çabalaması tüm sürecin birlikte değerlendirilmesini zorunlu kılmıştır.

2019 yılının son günlerinde Çin'de ortaya çıkan salgın çok kısa sürede tüm dünyaya yayılarak, 70 milyon vaka sayısına ulaşmış ve 1 milyondan fazla kişinin ölümüne yol açmıştır. Başta Dünya Sağllk Örgütü olmak üzere tüm ülkelerin sağlık uzmanları tarafından salgını durdurmak için maske, mesafe ve temizlik kurallarına uyulması konusunda uyarılar yapılmış,

\footnotetext{
${ }^{77}$ Jeffrey V Lazarus et al., "A Global Survey of Potential Acceptance of a COVID-19 Vaccine," Nature Medicine, 2020, 225.

${ }^{78}$ Facebook, "Keeping People Safe and Informed About the Coronavirus - About Facebook," 11 Aralık 2020, https://about.fb.com/news/2020/12/coronavirus/
} 
ülkeler sokağa çıkma kısıtlamaları ve karantina uygulamaları başlatmıştır. Dünya genelinde hareketliliğe getirilen bu sıkı uygulamalar ekonomik aktiviteleri durdurma noktasına getirmiştir. Dünya sağlık sistemleri ve ekonomilerinin üzerindeki bu baskıların kaldırılması ve hayatın normale dönebilmesi için en başarılı tıbbi yöntemlerden biri olan aşının geliştirmesi önem kazanmıştır. Hastalığın ilk ortaya çıkışından yaklaşık üç ay sonra ilk aşı geliştirme çalışmalarına başlandığı duyurulmuştur. Günümüze kadar geçen sürede bir dizi farklı teknik kullanan 200'den fazla aşı çalışmasının yürütüldüğü açıklanmıştır. Bu aşı adaylarından 162 'si klinik öncesi aşamada hayvanlara uygulanmakta olup, 59'u insanlar üzerinde uygulanmakta ve 16'sı testin son aşamalarına ulaşmış durumdadır. 2 aşı tam olarak kullanılma onayı alırken, 1 aşının çalışmaları durdurulmuştur. Ancak salgınının tüm dünyada ortadan kaldırılması için sadece aşıların geliştirilmesi yeterli değildir. Bu aşıların dağıtılması, uygun ortamlarda saklanması da aşıların üretilmesi kadar önem arz etmektedir.

Küresel ticaretin gelişmesi ve taşımacılık sürelerinin kısalması ile günümüzde soğuk zincir lojistiği birçok alanda başarıyla uygulanabilmektedir. Özellikle gıda sektöründe soğuk zincir uygulamaları oldukça fazla çeşit ürüne katma değer sağlamaktadır. Son yıllarda ilaç sektöründeki gelişmelerle yeni ilaçların soğuk zincire gereksinimi de artmıştır. 2017'de Amerikan Gıda ve İlaç Dairesi (FDA) tarafindan onaylanan 57 üründen 28 'i soğuk zincir ürünleri olmuş ve bunlardan 23'ünün 2-8 derece sıcaklık koşulları ve beşinin 0 derecenin altında oldukça düşük sıcaklık koşullarında saklanması gerekmektedir.

Yeni geliştirilen koronavirüs aşılarının da bazıları oldukça düşük sıcaklıklarda taşınma ihtiyacı soğuk zincir ihtiyacını tekrar gündeme getirmiştir. Dünya Sağlık Örgütü’nün raporlarına göre aşıların yaklaşık yarısı dağıtım sürecindeki soğuk zincirin bozulmasından kaynaklı olarak kullanılamaz hale gelmektedir. Aşıların üretiminden, enjekte edilmesine kadar aradaki sürecin belirli kontrol noktalarından takibi gerekmektedir. 


\section{Veli Ahmet ÇEviK}

Soğuk zincir gerektiren aşıların dağıtımında sıcaklık takibi yapılabilen taşınabilir taşıma kapları kullanılarak, bu süreçte görev alacak personellere gerekli eğitimlerin verilmesi gerekmektedir. Havacılık kuralları gereği tehlikeli madde olarak sınıflandırlan kuru buzlara bu süreçte oldukça fazla ihtiyaç duyulacağından, kuru buzların kullanılmasıyla ilgili gerekli eğitimlerin verilmesi de aşıların sağlıklı şekilde dağıtılmasını sağlayacaktır.

Aşıların geliştirilmeye başlandığının açıklanmasıyla ülkeler aşı siparişlerini vermeye başlamıştır. Ancak gelişmiş ülkelerin verdiği sipariş sayıları diğer ülkelere göre oldukça fazla olmuş, adeta aşı edinme yarışı başlamıştır. Hatta bazı ülkeler nüfuslarının altı yedi kat fazlası kadar aşı siparişi vermiştir. Aşıların üretilmesi kadar dağıtımı, adil şekilde tahsisi ve aşılara olan güvenin sağlanması konuları da toplumların bağışılılı kazanabilmesi için önem arz etmektedir. Sağlık uzmanlarının yaptığı açılklamalara göre, bağış̧ılık kazanılabilmesi için toplumların en az \%70'inin aşı olması gerekmektedir. Bu da tüm dünyada aynı anda bağışılılı kazanılmasıyla hastalığın ortadan kalkacağı anlamına gelmektedir. Dünyanın bir bölgesinin tamamen aşılanırken diğer bölgesi aşıdan yoksun kalırsa salgının bir yerlerde devam ettiği ve aşılananların bağışıklıklarını kaybettiği dönemlerde tekrardan salgına karşı savunmasız kalabileceği anlamına gelmektedir.

Geliştirilen etkili bir aşının sağlıklı şekilde dağıtılması da sürecin tamamlandığı anlamına gelmemektedir. Aşıların uygulanacağı bireylerin aşı olmaya istekliliği de diğer bir önemli konudur. Aşıların ilk geliştirildiği yıllardan beri toplumların aşılara karşı bir ön yargısı olmuştur. Bu ön yargıların oluşmasına, bilim adamları, büyük şirketlerin tanınan yöneticilerinin yaptığı açıklamalar ve medya ile yayılan komplo teorileri sebep olmuşlardır. Koronavirüs aşısının kabul durumunu araştıran son anketlerde de toplumların büyük bir kesimi aşıyı olmayacağını beyan etmişlerdir. COVID-19 aşısı yaptırmakta tereddüt edilen ana nedenler olası yan etkilerle ilgili endişeler, aşıların güvenliğini ve etkinliğini 
sağlamak için hükümetlere olan güven eksikliği, aşının çok yeni olduğu ve klinik deneylerin aceleye getirilmesi konusunda endişeler olmuştur.

Sonuç olarak, Covid 19 salgını ne son salgın ne de en kötü salgın olacaktır. Tüm ülkeler içinde bulunduğumuz salgından derslerini çıkarmalıdır. 2019'da Küresel Sağlık Güvenliği Endeksi, 85 gösterge ile her ülkenin pandemiye ne kadar hazır olduğunu değerlendirmiştir. Değerlendirme sonucuna göre, 195 ülkenin tümü arasında ortalama genel puan, 100 puan üzerinden 40,2 çıkmış ve ulusal sağlık güvenliğinin dünya genelinde temelde zayıf olduğu, hiçbir ülkenin salgınlara tam olarak hazırlıklı olmadığı ve her ülkenin ele alması gereken önemli boşlukları olduğu ortaya çıkmıştır.79

Aşının keşfinden bu yana ilk defa tüm dünyada aynı anda aşılara ihtiyaç duyulmuştur. Ülkelerin kendi toplumlarının sağlığını ön plana almak istemeleri sınırlı sayıda üretilen aşının adilce dağıtımına engel olmaktadır. Aşı üreticisi veya diğer gelişmiş ülkeler önce kendi nüfuslarını aşılamaya odaklandıklarından, küresel aşılama faaliyetleri yavaş bir ilerleme kaydetmektedir. Gelişmiş ülkeler finansman sağlayarak, aşı geliştirme uzmanlığını veya teknolojisini aktararak ve fikri mülkiyet kısıtlamalarını gevşeterek küresel arzı artırabilir. Her ne kadar zengin ülkelerin hükümetleri tarafindan hala engellenmekte olsa da, acil çözüm olarak, fikri mülkiyet ticaretini düzenleyen TRIPS (Ticaretle Bağlantılı Fikri Mülkiyet Anlaşması) kurallarından geçici olarak feragat etmek gereklidir. En azından böyle bir feragat salgının en şiddetli olduğu acil durum süresince sınırlı olabilir. Böylelikle yoksul ülkelere kendi aşılarını üretme yeteneği verilebilir veya aşılara kolay erişimin sağlanması için daha fazlası yapabilir.

Salgınların ortadan kaldırılması için "herkes güvende olana dek kimse güvende değildir” felsefesine uygun hareketle ülkelerin aşıları adil şekilde

${ }^{79}$ GHS Index, “The Global Health Security Index,” 31 Aralık 2020, https://www.ghsindex. org/about/ 


\section{Veli Ahmet ÇEViK}

edinmeleri gerekmektedir. Aşlar hakkındaki olumsuz düşüncelerin giderilmesi için toplumun ileri gelenleri tarafından bilgilendirilmesi, aşılara olan güveni sağlayacaktır.

\section{KAYNAKÇA}

Aday, Serpil, and Mehmet Seckin Aday. "Impact of COVID-19 on the Food Supply Chain.” Food Quality and Safety 4, no. 4 (2020): 167-180.

Al Theeb, N., Smadi, H. J., Al-Hawari, T. H., \& Aljarrah, M. H. (2020). Optimization of vehicle routing with inventory allocation problems in Cold Supply Chain Logistics. Computers \& Industrial Engineering, 142, 106341.

Üsküdar University Journal of Social Sciences, 2021; issue: 12 , $155-204$

Ali, Imran, Sev Nagalingam, and Bruce Gurd. "A Resilience Model for Cold Chain Logistics of Perishable Products." The International Journal of Logistics Management, 2018.

Arslan, İbrahim ve Soner Karagül. "Küresel Bir Tehdit (COVID-19 Salgını) ve Değişime Yolculuk.” Üsküdar Üniversitesi Sosyal Bilimler Dergisi, Sayı: 10 (2020): $1-36$.

Astrazeneca, "AZD1222 vaccine met primary efficacy endpoint in preventing COVID-19,” 4 Aralık 2020, https://www.astrazeneca.com/media-centre/ press-releases/2020/azd1222hlr.html.

Avac.org. “Time to Develop a Vaccine," 2 Aralık 2020. https://www.avac.org/ infographic/time-develop-vaccine.

Ball, Philip. "The Lightning-Fast Quest for COVID Vaccines - and What It Means for Other Diseases," Nature 589, No. 7840 (January 1, 2021): 16-18.

Balachandar, S, ve R Chinnaiyan. "Reliable pharma cold chain monitoring and analytics through Internet of Things Edge." Emergence of Pharmaceutical Industry Growth with Industrial IoT Approach, 133-161. Elsevier, 2020. 


\section{Covid-19 Aşısının Lojistiğinde Karşılaşılan Zorluklar}

BBC. “Covid-19: Milestones of the global pandemic," 25 Kasım 2020. https:// www.bbc.com/ news/world-54337098.

------.'Sinovac: Koronavirüs aşısı CoronaVac hakkında neler biliniyor," 4 Aralık 2020. https:// www.bbc.com/turkce/haberler-dunya-55162850.

Belluz, Julia, ve Umair Irfan. "AstraZeneca-Oxford Covid-19 vaccine: Why it’s different - Vox,” 14 Aralık 2020.https://www.vox.com/21590994/oxfordvaccine-results-covid-19-astrazeneca-trial-pfizer-moderna.

Biontech, "Press Releases | BioNTech," 4 Arallk 2020, https://investors. biontech.de/press-releases.

Chaudhuri, Atanu, Iskra Dukovska-Popovska, Nachiappan Subramanian, Hing Kai Chan, and Ruibin Bai. "Decision-Making in Cold Chain Logistics Using Data Analytics: A Literature Review." The International Journal of Logistics Management, 2018.

$\mathrm{CCDH}$. "The Anti-Vaxx Industry How Big Tech powers and profits from vaccine misinformation 2," 11 Aralık 2020. https://www.counterhate.co.uk/anti-vaxxindustry

Chance, Harjotsingh. "Cold Chain Logistics in Pharma," 27 Kasım 2020. https://www.hcltech.com/ blogs/cold-chain-logistics-pharma.

Chen, Elaine. "From 'Freezer Farms' to Jets, Logistics Operators Prepare for a Covid-19Vaccine," 11 Aralık 2020. https://www.wsj.com/articles/from-freezerfarms-to-jets-logistics-operators-prepare-for-a-covid-19-vaccine-11598639012.

DHL. "Delivery of COVID-19 vaccine: DHL study shows how public and private sector can partner for success," 14 Aralık 2020. https://www.dpdhl. com/en/media-relations/press-releases/2020/ delivery-covid-19-vaccine-dhlstudy-shows-how-public-and-private-sector-can-partner-for-success.html. 


\section{Veli Ahmet ÇEViK}

Duke Global Health Innovation Center, "Vaccine Procurement" 14 Nisan 2021, https://launchandscalefaster.org/covid-19/vaccineprocurement

Eccleston-Turner, Mark, and Harry Upton. "International Collaboration to Ensure Equitable Access to Vaccines for COVID-19: The ACT-Accelerator and the COVAX Facility." The Milbank Quarterly, 2021.

Euronews.com. "Global COVID Vaccine Inequality 'becoming More Grotesque Every Day,' WHO Warns” 12 Nisan 2021. https://www.euronews. com/2021/03/22/global-covid-vaccine-inequality-becoming -more-grotesqueevery-day-who-warns.

Eva Dou, "China coronavirus vaccine race is muddied by history of bribes

Üsküdar University Journal of Social Sciences, 2021; issue: 12 , $155-204$ at Sinovac,” 15 Aralık 2020, https://www.washingtonpost.com/world/ asia_pacific/coronavirus-vaccine-china-bribery-sinovac/2020/12 /04/7 c09ae68-28c6-11eb-9c21-3cc501d0981f_story.html.

Duijzer, Lotty Evertje, Willem van Jaarsveld, ve Rommert Dekker. "Literature review: The vaccine supply chain." European Journal of Operational Research 268, Say1 1 (2018): 174-192.

EMA. "Cyberattack on the European Medicines Agency," 11 Aralık 2020. https://www. ema.europa.eu/en/news/cyberattack-europeanmedicines-agency.

Europhia Consulting. "Key Transport Challenges In Covid-19 Vaccine Distribution,” 12 Aralık 2020. https://europhia.com/covid-19-supplychain

Facebook. "Keeping People Safe and Informed About the Coronavirus," 11 Aralık 2020. https: / /about.fb.com/news/2020/12/ coronavirus/.

Funk, Colin D, Craig Laferrière, ve Ali Ardakani. "A snapshot of the global race for vaccines targeting SARS-CoV-2 and the COVID-19 pandemic." Frontiers in pharmacology 11 (2020): 1-17. 
Covid-19 Aşısının Lojistiğinde Karşılaşılan Zorluklar

Gavi.org. "The Gavi COVAX AMC Explained | Gavi, the Vaccine Alliance," 12 Nisan 2021. https://www.gavi.org/vaccineswork/gavi-covax-amcexplained

GHS Index. “The Global Health Security Index,” 31 Aralık 2020. https:// www.ghsindex.org/about/.

Grady, Denise. "Moderna Is Applying for Emergency F.D.A. Approval for Its Coronavirus Vaccine - The New York Times,” 4 Aralık 2020. https:// www.nytimes.com/2020/11/30/health/covid-vaccine-moderna.html.

Gruber, Andrea. "Global Distribution and Flow of Vaccines Throughout the Supply Chain,” 11 Aralık 2020. https://www.iata.org/contentassets/ a80dd566681a4adfabccc43041abdcfb/transport-of-vaccines-webinar-2slides.pdf

Güler, Savaş. “Gıdaların Muhafazasında Soğuk Zincir Süreci,” 27 Kasım 2020. www.essiad.org.tr.

Guterl, Fred. "Vaccines Won't Stop the Pandemic Unless at Least 50 Million Skeptical Americans Change Their Minds," 29 Kasim 2020. https://www. newsweek.com/2020/11/27/vaccines-wont-stop-pandemic-unlessleast-50-million-skeptical-americans-change-their-minds-1549274.html.

IATA. “IATA - Home,” 25 Kasim 2020. https://www.iata.org/.

------.'IATA - The Time to Prepare for COVID-19 Vaccine Transport is Now,” 14 Aralık 2020. https://www.iata.org/en/pressroom/pr/202009-09-01/.

IEA. “Oil Market Report - April 2020 - Analysis,” 26 Kasım 2020. https:/ / www.iea.org/reports/oil-market-report-april-2020.

İngiltere Halk Sağlığı. "Why vaccinate?-Public health matters," 27 Kasım 2020. https:// publichealth matters.blog.gov.uk/ 2014/05/01/whyvaccinate/. 


\section{Veli Ahmet ÇEviK}

IPSOS. "COVID-19 vaccination intent is decreasing globally," 14 Aralık 2020. https://www.İpsos .com/en/global-attitudes-covid-19-vaccineoctober-2020.

Kay, Chris, Jason Gale, and Michelle Cortez. "Vaccine Nationalism in India, Europe Keep World's Poor Waiting," 12 Nisan 2021. https://www. bloombergquint.com/coronavirus-outbreak/curbs-by-world-s-biggestvaccine-exporter-to-hit-poorest-nations

Keaten, Jamey. "WHO: 10\% of world's people may have been infected with virus,” 12 Aralık 2020. https://news.yahoo.com/10-worlds-peoplemay-infected-114759146.html

Üsküdar University Journal of Social Sciences, 2021; issue: 12 , 155-204

Kingsley, Patrick. "Israel SecretlyAgrees to Fund Vaccines for Syria as Part of Prisoner Swap” 12 Nisan 2021.https://www.nytimes.com/2021/02/20/ world/middleeast/israel-syria-prisoner-swap-vaccines.Html.

Korucuk, SELÇUK. "Soğuk zincir taşımacıllğı yapan işletmelerde 3pl firma seçimi: İstanbul örneği.” Iğdır Üniversitesi Sosyal Bilimler Enstitüsü Dergisi 16 (2018): 341-365.

Moore, K. A., Lipsitch, M., Barry, J. M., \& Osterholm, M. T. “COVID-19: the CIDRAP viewpoint. Part 1: The future of the COVID-19 pandemic: lessons learned from pandemic influenza”. 2020, 1-9.

Kumar,N.,veJha,A. "Application of principles of supply chain management to the pharmaceutical good transportation practices". International Journal of Pharmaceutical and Healthcare Marketing. (2019)

Küçüktürkmen, Berrin, ve A Bozkır. "Özel saklama koşulu gerektiren veya soğuk zincire tabi ilaçlar ve uygulamalar açısından değerlendirmeler.” Türk Hijyen ve Deneysel Biyoloji Dergisi. Interest Group, 2018.

Larson, Paul D. "A Note on Mail Surveys and Response Rates in Logistics Research.” Journal of Business Logistics 26, No. 2 (2005): 211-222. 
Covid-19 Aşısının Lojistiğinde Karşılaşılan Zorluklar

Launchandscalefaster.org. "COVID-19 | Launch and Scale Speedometer," 5 Aralık 2020. https: / /launc handscalefaster.org/COVID-19.

Lazarus, Jeffrey V, Scott C Ratzan, Adam Palayew, Lawrence O Gostin, Heidi J Larson, Kenneth Rabin, Spencer Kimball, ve Ayman El-Mohandes. "A global survey of potential acceptance of a COVID-19 vaccine." Nature medicine, 2020, 1-4.

Li, Xuefeng, Ying Wang, and Xi Chen. "Cold Chain Logistics System Based on Cloud Computing." Concurrency and Computation: Practice and Experience 24, No. 17 (2012): 2138-2150.

Lin, Qi, Qiuhong Zhao, and Benjamin Lev. "Cold Chain Transportation Decision in the Vaccine Supply Chain.” European Journal of Operational Research 283, No. 1 (2020): 182-195.

Lloyd, John, ve James Cheyne. "The origins of the vaccine cold chain and a glimpse of the future." Vaccine 35, say1 17 (19 Nisan 2017): 2115-2120.

Matthias, Dipika M., Joanie Robertson, Michelle M. Garrison, Sophie Newland, and Carib Nelson. "Freezing Temperatures in the Vaccine Cold Chain: A Systematic Literature Review." Vaccine 25, No. 20 (May 16, 2007): 3980-3986.

Mercier, Samuel, Martin Mondor, Ultan McCarthy, Sebastien Villeneuve, Graciela Alvarez, ve Ismail Uysal. "Optimized cold chain to save food." içinde Saving Food, 203-26. Elsevier, 2019.

Ndraha, Nodali, Hsin I. Hsiao, Jelena Vlajic, Ming Feng Yang, ve Hong Ting Victor Lin. "Time-temperature abuse in the food cold chain: Review of issues, challenges, and recommendations." Food Control. Elsevier Ltd, 1 Temmuz 2018.

Nizamlıŏlu, Nizam Mustafa, ve Süleyman Gökmen. "Karaman ilindeki soğuk depolarının mevcut durumu, sorunları ve çözüm önerileri,” Derim Dergisi, Sayı: 34, 2017. 


\section{Veli Ahmet ÇEViK}

O'Halloran, M. (2021). Taoiseach warns against global interruption of vaccine delivery. https://www.irishtimes.com/news/politics/taoiseachwarns-against-global-interruption-of-vaccine-delivery-1.4518904

Okyay, Pınar. "Covid-19 Aşı Çalışmaları,” 10 Aralık 2020, https://www. ttb.org.tr/kutuphane/covid19-rapor_6/covid19-rapor_6_Part24.pdf.

Paris, Costas, ve Jared S. Hopkins. "Pfizer Sets Up Its 'Biggest Ever' Vaccination Distribution Campaign,” 11 Aralık 2020. https://www.wsj. com/articles/pfizer-sets-up-its-biggest-ever-vaccination-distrib utioncampaign-11603272614

Pfizer. "COVID-19 Vaccine U.S. Distribution Fact Sheet," 6 Aralık 2020. https://www.pfizer.com/news/hot-topics/covid_19_vaccine_u_s

Üsküdar University Journal of Social Sciences, 2021; issue: 12 , $155-204$ distribution_fact_sheet.

Poonawalla, A. Twitter post. 16 Nisan 2021, 11:46 a.m., https://twitter. com/adarpoonawalla

Rodrigue, Jean-Paul, ve Theo Notteboom. "The cold chain and its logistics." The geography of transport systems, 2014.

So, Anthony D, ve Joshua Woo. "Reserving coronavirus disease 2019 vaccines for global access: cross sectional analysis." bmj 371 (2020).

Standage, Tom. "Send for the Orphans: How the Smallpox Vaccine Crossed the Globe," 12 Nisan 2021. https://www.economist. com/1843/2021/04/08/send-for-the-orphans-how-the-smallpoxvaccine-crossed-the-globe

Stirlingultracold.com. "Unmatched $80^{\circ} \mathrm{C}$ Storage Advantages Across the COVID-19 Vaccine Cold Chain,” 5 Aralık 2020. https://www. stirlingultracold.com/wp-content/uploads/2020/09/C-19_VaccineDistribution_White-Paper_Stirling_Ultracold.pdf

T.C. Sağlık Bakanlığı. “Aşının Yolculuğu,” 2 Aralık 2020. https://asi.saglik. gov.tr/asinin-yolculugu 
Covid-19 Aşısının Lojistiğinde Karşılaşılan Zorluklar

TAPA. “TAPA: $€ 10$ Million In Product Losses In October As Major Cargo Thefts In Emea Average €686,300,” 11 Aralık 2020. https://tapa. memberclicks.net/assets/docs/2020_VIGILANT_WEB/TAPA\%20 Vigilant\%20e-Magazine\%20-\%20November\%202020\%20Issue.pdf

Testart, Alain, Richard G Forbis, Brian Hayden, Tim Ingold, Stephen M Perlman, David L Pokotylo, Peter Rowley-Conwy, and David E Stuart. "The Significance of Food Storage among Hunter-Gatherers: Residence Patterns, Population Densities, and Social Inequalities [and Comments and Reply]." Current Anthropology 23, No. 5 (1982): 523-537.

The Economist. "Daily chart - Rich countries grab half of projected covid-19 vaccine supply | Graphic detail," 29 Kasım 2020. https://www. economist.com/graphic-detail/2020/11/12/rich-countries-grab-halfof-projected-covid-19-vaccine-supply.

------."The roar of the crowd - Nothing can beat a live event Special report,” 3 Aralik 2020. https://www.economist.com/special-report/2017/02/09/ nothing-can-beat-a-live-event

------..Almost One Billion Doses of Covid-19 Vaccines Have Been Produced," 12 Nisan 2021. https://www.economist.com/ international/2021/03/31/almost-one-billion-doses-of-covid-19vaccines-have-been-produced

------. "American export controls threaten to hinder global vaccine production”. 6 Mayis 2021. https://www.economist.com/science-andtechnology/2021/04/22/american-export-controls-threaten-to-hinderglobal-vaccine-production

------. “Clinical Trials," 27 Mayıs 2021, https://www.who.int/healthtopics/clinical-trials

UN.org. "With More Than 1.5 Million Lives Lost to COVID-19, World Leaders in General Assembly Demand Urgent Action to Guarantee 


\section{Veli Ahmet ÇEviK}

Equitable Distribution of Life-Saving Vaccines | Meetings Coverage and Press Releases," 5 Aralık 2020. https://www.un.org/press/en/2020/ ga12293.doc.htm

UNCTAD. “Review of Maritime Transport 2020,” 25 Kasim 2020. https://unctad.org/webflyer/ review-maritime-transport-2020.

UNWTO. "Impact assessment of the COVID-19 outbreak on international tourism,” 25 Kasim 2020. https://www.unwto.org/impact-assessmentof-the-covid-19-outbreak-on-international-tourism

Wakefield, A. J., S. H. Murch, A. Anthony, J. Linnell, D. M. Casson, M. Malik, M. Berelowitz, vd. "Retracted: Ileal-lymphoid-nodular hyperplasia,

Üsküdar University Journal of Social Sciences, 2021; issue: 12 , 155-204 non-specific colitis, and pervasive developmental disorder in children." Lancet 351, Say1: 9103 (28 Şubat 1998): 637-641.

Weise, Elizabeth. "Pfizer's COVID-19 vaccine is spiking sales of dry ice. Here's why.," 11 Aralı 2020. https://www.usatoday.com/story/ news/health/2020/11/18/pfizer-covid-19-vaccine-dry-ice-salesstorage/6281859002/

WHO. "Draft landscape of COVID-19 candidate vaccines," 24 Kasım 2020. https://www.who.int/ publications/m/item/draft-landscape-ofcovid-19-candidate-vaccines.

------. "Draft landscape of COVID-19 candidate vaccines," 24 Kasım 2020. https://www.who.int/ publications/m/item/draft-landscape-ofcovid-19-candidate-vaccines.

------. "Immunization Supply Chain And Logistics," 6 Aralı 2020. https://www.who.int/immunization/call-to-action_ipac-iscl.pdf.

------. "Monitoring vaccine wastage at country level Guidelines for programme managers Immunization, Vaccines and Biologicals," 6 Aralık 2020. www.who.int/vaccines-documents/ 
Covid-19 Aşısının Lojistiğinde Karşılaşılan Zorluklar

."Qualification of temperature-controlled storage areas," 6 Aralik 2020. https://www.who.int/biologicals/expert_committee/ Supplement-7-TS-qualification-storage-areas

."Vaccines and immunization,” 24 Kasim 2020. https://www.who. int/health-topics/vaccines-and-immunization\#tab=tab_1

"WHO Concept for fair access and equitable allocation of COVID-19 health products,” 24 Kasim 2020. https://www.who.int/ docs/default-source/coronaviruse/who-covid19-vaccine-allo cation final-working-version-9sept.pdf?sfvrsn=e1d0376_6\&download=true.

------.'WHO Zaman Çizelgesi - COVID-19,” 24 Kasım 2020. https:// www.who.int/news/item/27-04-2020-who-timeline---covid-19

Workman, D. "Drugs and medicine exports by country. World's Top Exports.” 27 Mayis 2021. http://www. worldstopexports. com/drugsmedicine-exports-country.

Worldometers.info. "Coronavirus Update (Live): 59,562,713 Cases and 1,402,934 Deaths from COVID-19 Virus Pandemic-Worldometer," 24 Kasim 2020. https://www.worldometers.info/coronavirus/?

Yavuz, Fahri, Ayşe Sezgin, ve Okan Demir. "Erzurum Sütçülük Sektöründe Soğuk Zincir İyi Uygulama Örneklerinin Oluşturulması ve Yayınlaştırılması Üzerine Bir Çalışma." Tarım Ekonomisi Araştırmaları Dergisi 2, Sayı: 1 (2016): 42-50.

Yazıcı, Sabire. “Covid-19'un Soğuk Zincir Lojistiğine Etkisi.” Journal of Awareness 5, Sayı: 3 (2020): 391-400.

Zhou, Peng, Xing-Lou Yang, Xian-Guang Wang, Ben Hu, Lei Zhang, Wei Zhang, Hao-Rui Si, Yan Zhu, Bei Li, ve Chao-Lin Huang. "A pneumonia outbreak associated with a new coronavirus of probable bat origin." Nature 579, Sayı: 7798 (2020): 270-273. 


\section{Veli Ahmet ÇEViK}

Zimmer, Carl, Jonathan Corum, ve Sui-Lee Wee. "Covid-19 Vaccine Tracker: Latest Updates - The New York Times,” 15 Aralık 2020. https:// www.nytimes.com/interactive/2020/science/coronavirus-vaccinetracker.html

Üsküdar

University

Journal

of Social

Sciences, 2021;

issue: 12 ,

$155-204$ 